\title{
Classification of the relict forest communities of Palla's Black Pine (Pinus nigra subsp. pallasiana) in Bulgaria
}

\author{
Rossen Tzonev ${ }^{1}$, Marius Dimitrov ${ }^{2}$, Chavdar Gussev ${ }^{3}$, Vladimir Vulchev ${ }^{3} \&$ \\ Ivailo Nikolov ${ }^{4}$
}

Keywords: Balkan Peninsula, coniferous forests, vegetation, syntaxonomy, cluster analysis.

Ključne besede: Balkanski polotok, gozdovi iglavcev, vegetacija, sintaksonomija, klastrska analiza.

\begin{abstract}
New approach for the classification of the Black Pine forest communities in Bulgaria was made in the paper. The analysis of forest pytocoenoses from Vlahina, East and West Rhodopi and Balkan Range Mountains confirmed their separation into two classes - Quercetea pubescentis (low-altitudinal) and Erico-Pinetea (highaltitudinal). The second class is represented from one polymorphic association Seslerio latifoliae-Pinetum nigrae whereas the other group is represented from two new associations. The association Junipero deltoidi-Pineteum pallasianae is more related to the surrounding thermophilous oak forests as well as the association Lathyro laxiflori-Pinetum pallasianae is more similar to the hornbeam and beech forests.

Izvleček

$\mathrm{V}$ članku predstavljamo nov pristop k klasifikaciji gozdov črnega bora v Bolgariji. $\mathrm{Z}$ analizo gozdnih fitocenoz z območja Vlahina, vzhodnih in zahodnih Rodopov in gorovja Balkan, smo potrdili njihovo uvrstitev v dva razreda - Quercetea pubescentis (na nižjih nadmorskih višinah) and Erico-Pinetea (na višjih nadmorskih višinah). Slednji je zastopan z eno polimorfno asociacijo Seslerio latifoliae-Pinetum nigrae, prvi razred pa predstavljata dve novi asociaciji. Asociacija Junipero deltoidiPineteum pallasianae je povezana s sosednjimi termofilnimi hrastovimi gozdovi, medtem ko je asociacija Lathyro laxiflori-Pinetum pallasianae bolj podobna gabrovim in bukovim gozdovom.
\end{abstract}

Received: 16. 5. 2017

Revision received: 27.9 .2017

Accepted: 2. 10. 2017

\footnotetext{
1 Department of Ecology and Environmental Protection, Faculty of Biology, Sofia University “St. Kliment Ohridski”, 8 Dragan Tzankov Blvd., Sofia 1164, Bulgaria. E-mail: rossentzonev@abv.bg

2 Department of Dendrology, Faculty of Forestry, Forestry University, 10 Kliment Ohridsky Blvd., Sofia 1797, Bulgaria. E-mail: mariusdimitrov@ltu.bg

3 Division of Applied Botany, Department of Botany and Mycology, Institute of Biodiversity and Ecosystem Research, Bulgarian Academy of Sciences, 10 Gagarin Str., Sofia 1113, Bulgaria. E-mail: chgussev@gmail.com, vlado@bio.bas.bg

4 Directorate of Central Balkan National Park, 3 Bodra Smyana Str., Gabrovo 5300, Bulgaria. E-mail: ivodimnik@abv.bg
} 


\section{Introduction}

The Black pine (Pinus nigra) has wide range of distribution occupying territories from Central and South Europe to the South-West Asia and in this range it is strongly variable (Gaussen et al. 1993). Several subspecies are known from the different parts of Europe and Asia Minor but especially the subspecies Pinus nigra subsp. pallasiana occurs in Bulgaria (see Stoyanov 1963, Gaussen et al. 1993, Liber et al. 2003, etc.). Strong variability amongst the populations of Black Pine in Bulgaria also was recorded (Naydenov et al. 2006, 2015) which is a good evidence for their relict origin and the insular isolation within the surrounded forest types dominated from oak, beech or other coniferous species, mostly Picea abies and Pinus sylvestris.

According to Bondev (1991, 2002) and Roussakova \& Valchev (2015) the communities of Black Pine belong to the Mediterranean vegetation forest type in Bulgaria. The species is xerothermic with large range of altitude, from 400 up to $1800 \mathrm{~m}$ alt. Presently, the main part of the Black pine forests in Bulgaria occur between (600) 800 and 1300-1500 m alt., mainly in steep slope areas. The forests occur in different vegetation belts, from the xerothermic oak belt, through the mesophilous hornbeam-beech forests up to the microthermic coniferous forests. Hence they fall within different climatic and phytogeographical territorial subdivisions which also reflect on their classification. These forest communities occur mostly in Rhodope, Vlahina and Pirin Mts. and to a more limited extent in Slavyanka, Rila, Osogovo Mts., the low mountains of West Bulgaria, the Balkan Range and Forebalkan (Roussakova \& Valchev 2015). According to Panayotov \& Yurukov (2016) the natural Black Pine forests in Bulgaria cover area about 37500 ha. This calculation is a little bit different from the area cited in the Red Data Book of Bulgaria, vol. 3 - 39940 ha (see Gussev \& Tzonev 2015) on the basis of models produced from Bulgaria Forest Database.

These communities have conservation significance because the habitat of Black Pine is included in Annex № 1 of Habitat Directive and Bulgarian Biodiversity Act and is of conservation priority. Parts of the communities of $P i$ nus nigra subsp. pallasiana are within protected areas and in sites from the European Ecological Network NATURA 2000. Some of the Bulgarian reserves like Chamdzha, Kazanite, Kastrakli, Boraka, Gabra, Borovec, etc. were especially established to protect the genetic resources of natural Black Pine forests. The Black Pine communities also were assessed in the Red List Assessment of European Habitats (see Janssen et al. 2016) as "Least Concern" within the habitat G3.4b Temperate and submediterranean montane Pinus sylvestris-nigra woodland.
The natural and human-forested communities of Black Pine have significant importance in Bulgaria (Vlasev 1966). They are used as a construction material, for resin, and by the local people for the production of pine splinters. It has also ornamental features. But also thousands of hectares have been planted because of aesthetic and anti-erosion purposes in many areas in Bulgaria where the species is not native. According to Panayotov \& Yurukov (2016) the Black Pine plantations in Bulgaria occupy one area of 272000 ha (7 times more than the natural forests) and near $80 \%$ of them are in the altitudinal belt between 0 and 700 $\mathrm{m}$. But the origin of genetic material in many cases is not known and even is from different subspecies and also hybrids from France, Italy and other European countries.

The natural communities of Black Pine in Bulgaria have been object of numerous studies according to the dominant methodology (see Lavrenko 1959) most of them summarised by Apostolova \& Slavova (1997). Mainly they were focused on these Black Pine forests in the protected areas and especially the reserves like Borovec (Bondev \& Lyubenov 1985), Chamluka (Bondev \& Lyubenova 1985), Gabra (Bondev \& Lazarov 1995, Gussev et al. 2005), Boraka (Velchev et al. 1985), Kastrakli (Meshinev 1985), Chervenata Stena (Nikolov \& Nikolov 1984) as well as some mountain areas in Bulgaria like the basin of Chepelarska river and south of Smolyan Town in Rhodope Mts. (Gorunova \& Kochev 1992, Meshinev 1995), Osogovska Mts. (Zahariev 1934, Lazarov 1995), Plana Mts. (Penev 1938), Vitosha Mt. (Petkov 1921), Middle Rhodopi (Stranski 1921), Slavyanka Mt. (Stoyanov 1921) or specific communities like these ones with Black Pine and Bearberry (see Roussakova et al. 1991). Some data for the structure and the distribution of the Black Pine forests in Bulgaria also have in the works of Bondev \& Yordanova (1973), Bondev (1991, 2002), Velchev (2002) and Roussakova et al. (1991). The habitat of Black Pine forests in Bulgaria (36G3 Forests of Black pine (Pinus nigra subsp. pallasiana)) was described by Roussakova \& Valchev (2015). Only study according to the Braun-Blanquet methodology is the recent research of the flora and vegetation of Chamdzha Reserve in Stara Planina Mts. (Vassilev \& Gavrilova 2016), but because of insufficient phytocoenological materials the syntaxon was given only on a community level.

The studies on these communities on the Balkan and Western Anatolian Peninsula are more numerous but most of them are not very close to Bulgaria and therefore not provide sufficient information to conclude for the classification of such communities in this central part of Balkan Peninsula. More or less complete information for Black Pine forests from the surrounding countries of Bulgaria was given for Greece (Debazac 1970, Barbero 
\& Quezel 1976, Bergmeier 1990, 2002, Dimopoulos \& Georgiadis 1995, etc.), Albania (Dring et al. 2002), the countries of former Yugoslavia (Em 1962, 1978, Domac 1965, Mišić 1981, Trinajstić 1986, 1998, Škorić \& Vasić (eds.) 2006, Zupančič 2007, Popović et al. 1997, Milosavljević et al. 2008, Ostojić \& Jovanović 2008, Sedlar et al. 2011, etc.), Turkey (Aksoy \& Gemici 1980, Akman et al. 1979, Quézel et al. 1980, Ketenoğlu et al. 2010, etc), as well as the whole Balkan Peninsula or some parts of the Mediterranean region (Horvat 1959, Horvat et al. 1974, Debazac 1971, Seibert 1992, Regato et al. 1995, Poldini \& Vidali 1999, Brullo et al. 2001).

The aim of the present study is to make an attempt to establish classification sheme of the relict natural communities of Palla's Black Pine forests in Bulgaria. More detail descriptions of their ecological, floristic and dynamic peculiarities and their origin also were object of this research.

\section{Material and methods}

The plant communities of study sites were investigated during the period between years 1991-2014. The principles and methods of the Zürich-Montpellier School (Braun-Blanquet 1964, Mueller-Dombois \& Ellenberg 1974, Westhoff \& van der Maarel 1978) were applied.
The sample plot size varies between 200 to 600 sq. m because of the open structure of Black Pine forests. More than 100 relevés were used to cover some of the most important localities of Black Pine communities in Bulgaria like East and West Rhodope, Central Balkan Range, Vlachina Mountains, etc. (Figure 1). At each sampling plot a complete list of the present species (vascular plants) was recorded, together with their cover-abundance value according to the 7-degree Braun-Blanquet scale and transformed as proposed by van der Maarel (1979). The plant nomenclature follows Delipavlov et al. (2003).

All data analysis was performed with the SYN-TAX 2000 program package (Podani 2001). Average linkage method (UPGMA) and Principal Coordinate Analysis ( $\mathrm{PCoA}$ ) were used to evaluate floristic similarity between relevés or respectively established syntaxa according to the Horn's index (Horn 1966). UPGMA (Unweighted Pair Group Method with Arithmetic Mean) is a simple agglomerative or hierarchical clustering method used widespread in the phytocoenological studies (van der Maarel \& Franklin 2013). UPGMA clustering is more robust and has a better goodness of fit to dissimilarities than complete and single linkage classifications (Podani \& Schmera 2006). The Horn's index is an information theoretic index of community similarity (commu-

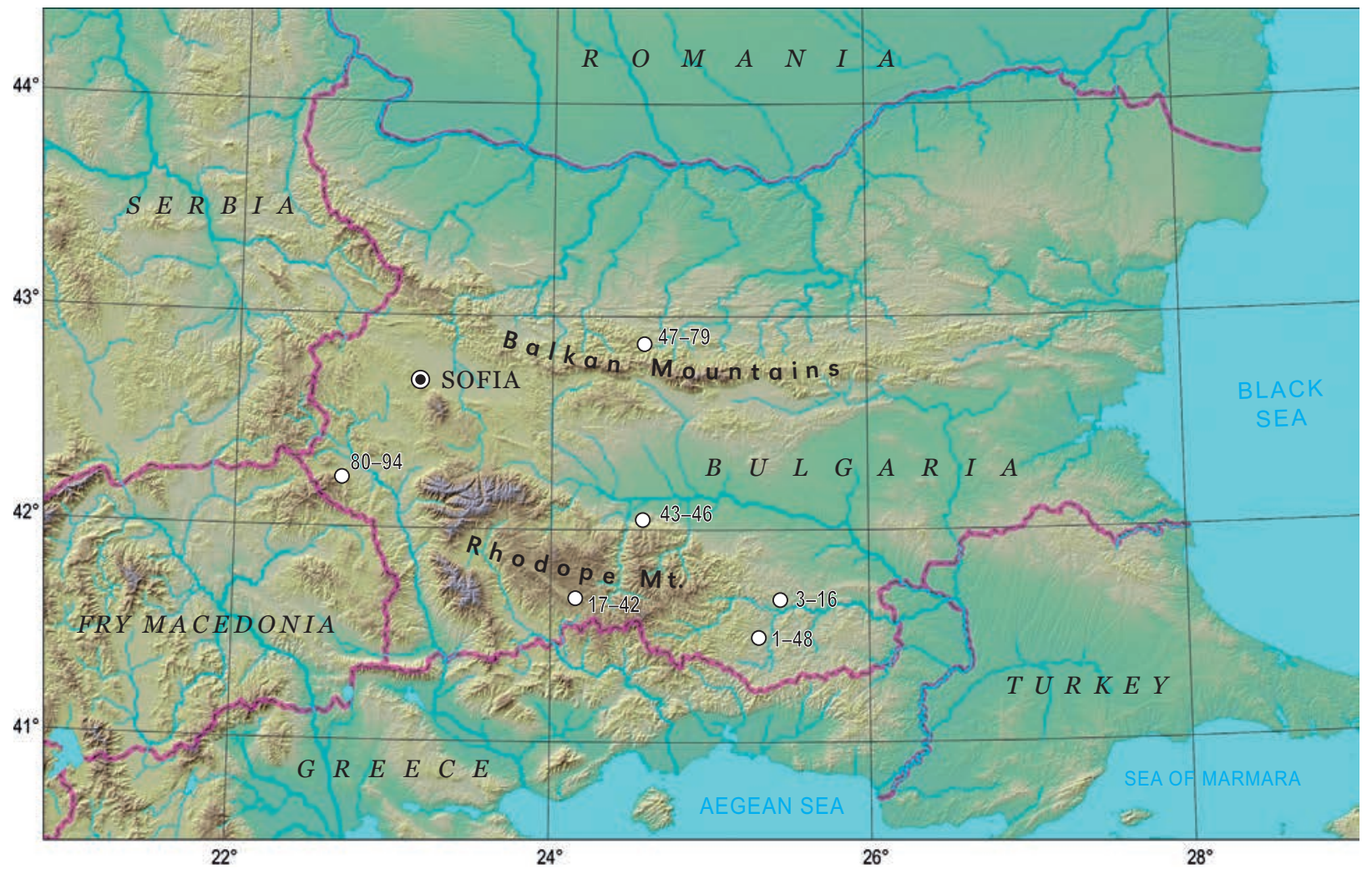

Figure 1: Map of studied communities in Bulgaria dominated from Pinus nigra subsp. pallasiana.

Slika 1: Zemljevid proučevanih združb z dominantno vrsto Pinus nigra subsp. pallasiana v Bolgariji. 
nity overlap), which is recommended to such researches (Brower et al. 1998).

The synaxa were compared according their floristic structure and the constancy classes of the taxa. The synoptic similarity also was evaluated using also PCoA and average linkage method (UPGMA) using Horn's index. Principal Coordinates Analysis ( $\mathrm{PCoA}=$ Multidimensional scaling, MDS) is a method to explore and visualize similarities or dissimilarities of data. It starts with a similarity matrix or dissimilarity matrix (= distance matrix) and assigns for each item a location in a low-dimensional space, e.g. as a $3 \mathrm{D}$ graphics. This analysis was pioneered by Gower (1966) as an alternative to PCA better suited to ecological datasets. This analysis was used in the study only on association level to establish the main gradient for differentiations amongst them.

The syntaxa names and the names of their authors are given according to ICPN (Weber et al. 2000). The leading for the determination of synoptic schema was the work of Mucina et al. (2016).

\section{Results}

The results of the analyses, demonstrated the existing of two main groups of Black Pine communities (Figure 2) that correspond to two vegetation classes. They could be presented in the following syntaxonomic scheme:
Class Quercetea pubescentis Doing-Kraft ex Scamoni et Passarge 1959

Order Quercetalia pubescenti-petraeae Klika 1933

Alliance Fraxino orni-Ostryion Tomažič 1940

Association Lathyro laxiflori-Pinetum pallasianae ass. nova hoc loco

Alliance Carpinion orientalis Horvat 1958

Association Junipero deltoidi-Pinetum pallasianae ass. nova hoc loco

Class Erico-Pinetea Horvat 1959

Order Erico-Pinetalia Horvat 1959

Alliance Fraxino orni-Pinion nigrae Em 1978

Association Seslerio latifoliae-Pinetum nigrae Em 1978 subass. typicum

Association Seslerio latifoliae-Pinetum nigrae Em 1978 subass. haberletosum subass. nova hoc loco

Pinus nigra subsp. pallasiana and Brachypodium pinnatum community

The first group of communities is on a lower altitude and on more xerophilous to xeromesophilous conditions. It could be related with the deciduous (oak, beech, hornbeam) forests. The species composition and ecological peculiarities of these communities are similar to the surrounding mostly oak forests. The deciduous trees like Quercus frainetto, Q. pubescens, Carpinus orientalis, Acer campestre, Fraxinus ornus, Pyrus pyraster, Sorbus torminal-

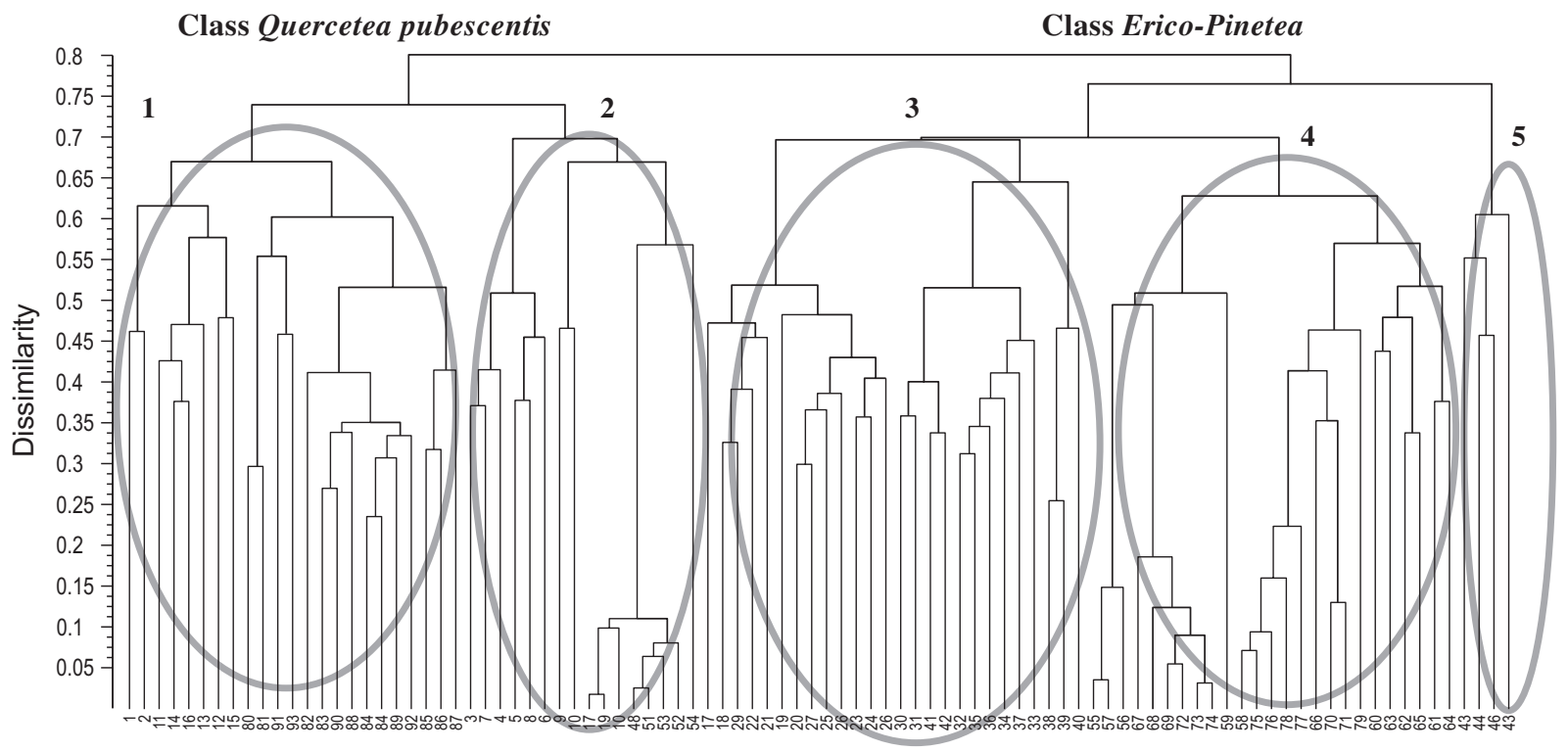

Figure 2: Cluster dendrogram of relevés with Pinus nigra pallasiana: 1. Ass. Lathyro laxiflori-Pinetum pallassianae; 2. Ass. Junipero deltoidi-Pinetum pallasianae; 3. Ass. Seslerio latifoliae-Pinetum nigrae typicum; 4. Ass. Seslerio latifoliae-Pinetum nigrae haberletosum; 5 . Pinus nigra pallasiana and Brachypodium pinnatum community.

Slika 2: Dendrogram popisov z vrsto Pinus nigra pallasiana: 1. As. Lathyro laxiflori-Pinetum pallassianae; 2. As. Junipero deltoidi-Pinetum pallasianae; 3. As. Seslerio latifoliae-Pinetum nigrae typicum; 4. As. Seslerio latifoliae-Pinetum nigrae haberletosum; 5 . Združba z vrstama Pinus nigra pallasiana in Brachypodium pinnatum. 
is, etc. can be co-dominant. The shrub layer is also typical for this forest type and includes species like Cornus mas, Corylus avellana, Cotinus coggygria, and Syringa vulgaris. The participation of Genista carinalis, Juniperus oxycedrus subsp. deltoides, etc. provides the Mediterranean outlook of these forests. The herbaceous vegetation is dominated by Brachypodium pinnatum, B. sylvaticum, Festuca heterophylla, Melica uniflora, Poa nemoralis, etc. Most of the Black Pine forests from this type are not in good condition as a result of the anthropogenic pressure and natural forest succession and really the Black Pine forests have remained like only small islands among the broad-leaved vegetation. At the higher altitude $(900-1200 \mathrm{~m})$ more typical for montane forest belt of the Bulgarian mountains prevail more mesophilous species like Quercus dalechampii, Fagus sylvatica, Carpinus betulus which also have similar shrub and herbaceous layers with these forests.

The second main group is more related to coniferous forests. The coniferous species are represented mostly from Abies alba and Picea abies. The dominant role of Sesleria latifolia is typical for the herbaceous layer of these high-altitudinal Black Pine forests.

According to the analysis three main associations were described - one of them already described in Former Yugoslavia (Em 1978) presents the communities from EricoPinetea. Two new associations belong to low-altitudinal Black Pine forests from Quercetea pubescentis. All associations are described below with their ecological, phytocoenological and floristic features.

Especially PCoA (Figure 3) well illustrated the main gradients which differentiate the studied communities. The humidity and altitude are decreasing from left to right on Axis 1. The most xerophytic and low-altitudinal is the association Junipero deltoidi-Pinetum pallasianae (2) which is close to more mesophilous Lathyro laxiflori-Pinetum pallasianae (1) and they both belong to Quercetea. Whereas, the class Erico-Pinetea is presented from two subassociations ( 3 and 4 ) of one association and also from one community (5) but witth a lower species richness.

\section{Association Lathyro laxiflori-Pinetum pallasianae ass. nova hoc loco (Table 1), holotypus rel. 11}

Diagnostic species for the association: Pinus nigra subsp. pallasiana (100\%), Aremonia agrimonoides (57\%), Lathyrus laxiflorus (48\%), Genista carinalis (35\%).

Constant species: Pinus nigra subsp. pallassiana (100\%), Quercus daleschampii (78\%), Melica uniflora (61\%), Fagus sylvatica (57\%), Aremonia agrimonioides (57\%).

This new association (Figure 4) is described from two remote regions of Bulgaria - Vlachina Mt. (Gabra Reserve) on western border with FYR Macedonia and East Rhodope Mts. (Zhenda Reserve). These communities are

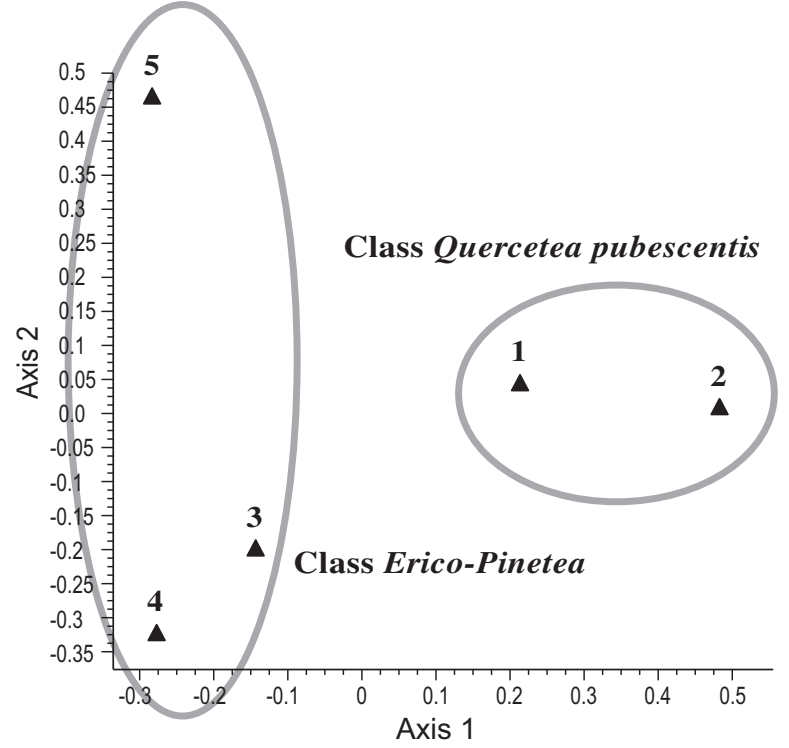

Figure 3: Ordination diagram of the established syntaxa: 1. Ass. Lathyro laxiflori-Pinetum pallassianae; 2. Ass. Junipero deltoidi-Pinetum pallasianae; 3. Ass. Seslerio latifoliae-Pinetum nigrae typicum; 4. Ass. Seslerio latifoliae-Pinetum nigrae haberletosum; 5. Pinus nigra pallasiana and Brachypodium pinnatum community.

Slika 3: Ordinacija ugotovljenih sintaksonov: 1. As. Lathyro laxifloriPinetum pallassianae; 2. As. Junipero deltoidi-Pinetum pallasianae; 3. As. Seslerio latifoliae-Pinetum nigrae typicum; 4. As. Seslerio latifoliae-Pinetum nigrae haberletosum; 5 . Združba z vrstama Pinus nigra pallasiana in Brachypodium pinnatum.

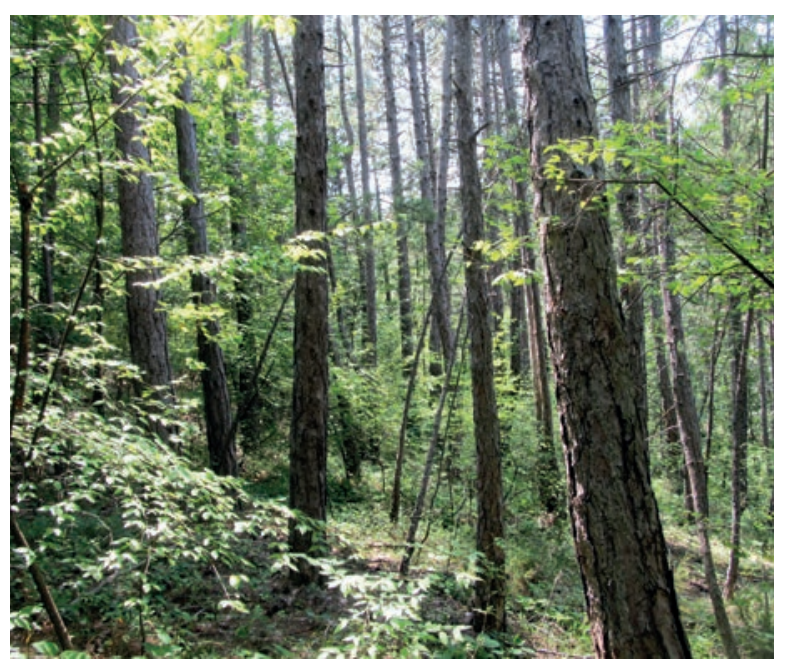

Figure 4: Stand of the association Lathyro laxiflori-Pinetum pallassianae in Borovec Reserve, East Rhodope Mts. Photo: Rossen Tzonev.

Slika 4: Sestoj asociacije Lathyro axiflori-Pinetum pallassianae v rezervatu Borovec, gorovje Vzhodni Rodopi. Foto: Rossen Tzonev.

more meso-xerophilous and represent the transitional type between typical low-altitudinal Black Pine communities from Quercetea pubescentis and the high-altitudinal mountain ones from Erico-Pinetea. They occupy the altitudinal 
belt between $500-1300 \mathrm{~m}$ alt., mostly $800-1000 \mathrm{~m}$. The exposition of the terrain is with northern component and the inclination varies between $8-45^{\circ}$ (mostly $30-40^{\circ}$ ). The canopy of tree layer is about $60 \%$ (from 40 to $80 \%$ ).

Besides with the dominant Pinus nigra, co-dominants are some mesophilous deciduous species (mostly belonging to Fagion sylvaticae) like Quercus daleschampii, Fagus sylvatica. The shrub layer is not well developed but the herbaceous species are typical also for the forests of Common Beech, Hornbeam or Sessile Oak. Such are Aremonia agrimonoides, Melica uniflora, Poa nemoralis, Galium odoratum, Sanicula europaea, Galium pseudaristatum, Dactylis glomerata, Hieracium murorum gr. The diagnostic species emphasize the relationships firstly with surrounding beech forests (Aremonia agrimonoides, Lathyrus laxiflorus) but also their relict and Balkan endemic origin (Genista carinalis).

\section{Association Junipero deltoidi-Pinetum pallasianae} ass. nova hoc loco (Table 1) holotypus rel. 47.

Diagnostic species: Pinus nigra subsp. pallasiana (100\%), Juniperus oxycedrus subsp. deltoides (88\%), Dianthus petraeus subsp. petraeus (44\%), Cotinus cogyggria (38\%).

Constant species: Pinus nigra subsp. pallasiana (100\%),
Juniperus oxycedrus subsp. deltoides (88\%), Fraxinus ornus (88\%), Quercus pubescens (88\%), Carpinus orientalis (75\%), Quercus dalechampii (69\%), Viola odorata (56\%).

This new association is the most xerophylous and with the strongest sub-Mediterranean influence mainly from the surrounding oak forests. The Black Pine communities have relict origin and insular isolation amongst the deciduous forest vegetation. Such forests have been established in the lowest parts of distribution of Black Pine communities in Bulgaria - East Rhodope Mts. (Borovec and Boraka Reserves) (Figure 5) and part of southern slopes of Central Balkan Range (Chamdzha Reserve and Meden Dol Locality) (Figure 6). Their distribution varies in the altitudinal belt between $300-700 \mathrm{~m}$ alt. (mostly 500-600). They occupy slopes with inclination nearby $30-45^{\circ}$ (between $12-45^{\circ}$ ) and with different expositions. It is mainly northern in East Rhodope Mts. but definitely south in the Balkan Range Mt.

The forests are open, dry and light. The canopy is mostly about $50-60 \%$. Pinus nigra subsp. pallasiana is a dominant or co-dominant with deciduous tree species like Quercus pubescens, Quercus dalechampii, Carpinus orienta-

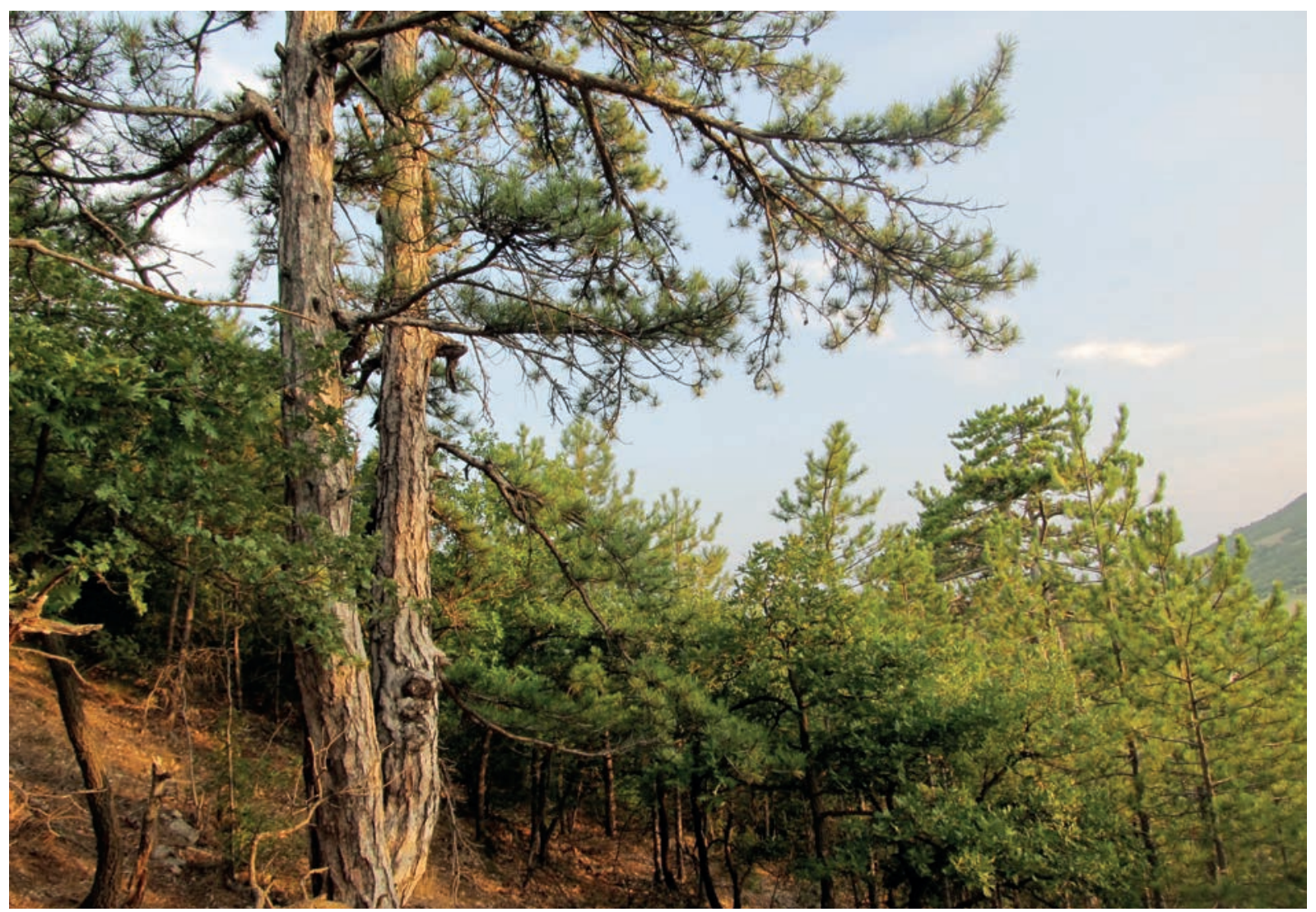

Figure 5: Stand of the association Junipero deltoidi-Pinetum pallassianae in Boraka Reserve, East Rhodope Mts. Photo: Rossen Tzonev. Slika 5: Sestoj asociacije Junipero deltoidi-Pinetum pallassianae, rezervat Boraka, gorovje Vzhodni Rodopi. Foto: Rossen Tzonev. 


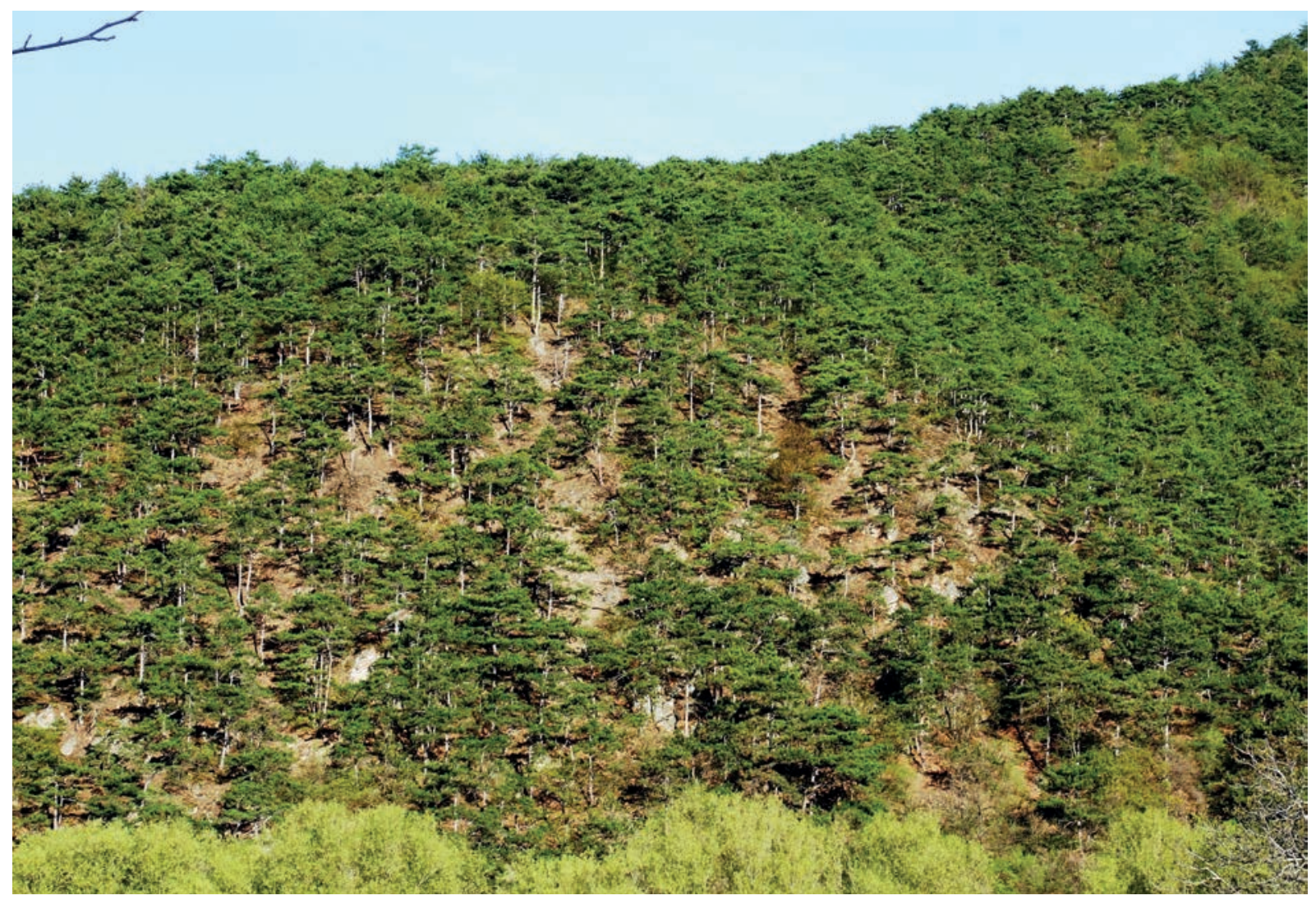

Figure 6: Stand of the association Junipero deltoidi-Pinetum pallassianae in Chamdzha Reserve, Central Balkan Mts. Photo: Ivajlo Nikolov. Slika 6: Sestoj asociacije Junipero deltoidi-Pinetum pallassianae, rezervat Chamdzha, gorovje Srednji Balkan. Foto: Ivajlo Nikolov.

lis, and Fraxinus ornus. The shrub layer is better developed comparing with the previous association. Juniperus oxycedrus subsp. deltoides participates in both geographical areas whereas Cotinus cogyggria is a dominant species in East Rhodope Mts. Other common species in shrub layer are Cornus mas and Crataegus monogyna. Widespread species like Brachypodium sylvaticum, Veronica chamaedrys, Viola odorata, etc. are typical for the herbaceous layer. Especially in Central Balkan Range, the forests are on calcareous rocky terrains where the hasmophytic Balkan endemics like Dianthus petraeus subsp. petraeus and Moehringia pendula could dominate in this layer. They are also diagnostic species together with South-East European subspecies of Juniperus oxycedrus - Juniperus oxycedrus subsp. deltoides and also Cotinus cogyggria which represents the relationships with the open oak forests and forest-steppes of South-East Europe.

\section{Association Seslerio latifoliae-Pinetum nigrae Em 1978 (Table 2)}

Diagnostic species for the association: Pinus nigra subsp. pallasiana (100\%), Sesleria latifolia (63\%), Iberis sempervirens (21\%), Daphne blagayana (14\%).
Constant species: Pinus nigra subsp. pallasiana (100\%), Fagus sylvatica (79\%), Calamagrostis arundinacea (74\%), Ostrya carpinifolia (70\%), Abies alba subsp. alba (70\%), Euphorbia amygdaloides (70\%), Fragaria vesca (60\%), Acer hyrcanum subsp. hyrcanum (54\%).

The group of communities in Bulgaria which belong to the class Erico-Pinetea (Figure 7) was included in the scope of described in Former Yugoslavia (FYR Macedonia) association Seslerio latifoliae-Pinetum nigrae Em 1978. Its range was expanded to all central Balkan Mountains and its floristic and ecological structure is accepted to be more polymorphic. This association is represented from different geographical synvicariant Black Pine communities distributed mostly inside the coniferous vegetation dominated from Scot Pine and/or Spruce. But these Pinus nigra communities, because of their lower competitive possibilities comparing with the dominant coniferous species, are isolated on not very large spots on some sometimes very steep and rocky slopes of mountain valleys or gorges. There is a clear dominant role of Sesleria latifolia in the herbaceous layer - Balkan endemic - ecological and geographical vicariant of some other similar species like Sesleria robusta in southern and western parts of the 


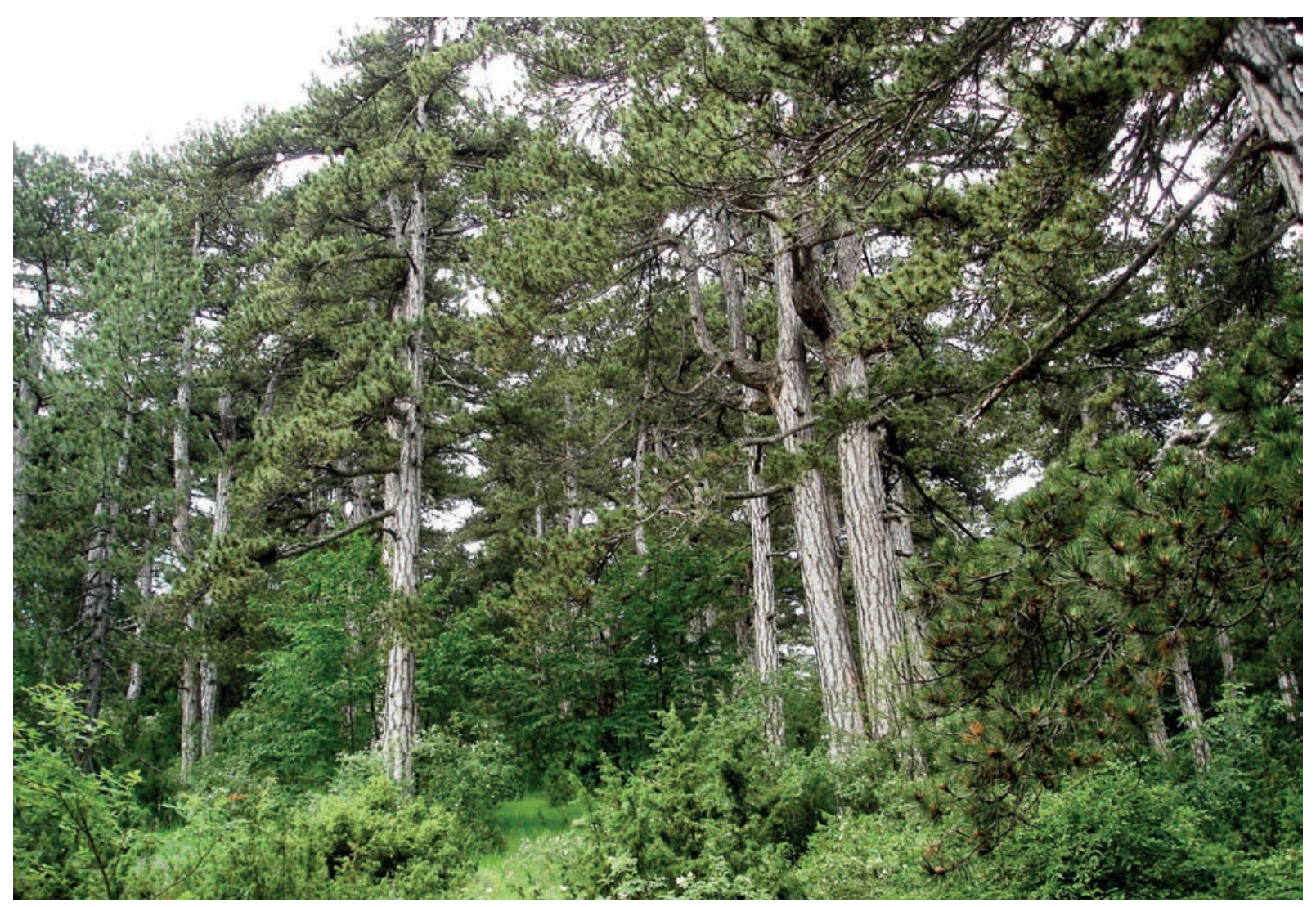

Figure 7: Stand of the association Seslerio latifoliae-Pinetum pallassianae in West Rhodope Mts., Dobrostan. Photo: Rossen Tzonev. Slika 7: Sestoj asociacije Seslerio latifoliae-Pinetum pallassianae v gorovju Zahodni Rodopi, Dobrostan. Foto: Rossen Tzonev.

Balkan Peninsula. This association is also synvicariant to the described in Kato Olimbos Seslerio robustae-Pinetum pallasianae Barbero et Quezel 1976 corr. Bergmeier 1990, which is similar but richer in endemic and oro-mediterranenan species. Such species are Sesleria robusta, Centaurea pindicola, Polygala nicaeensis subsp. mediterranea, etc.

The association Seslerio latifoliae-Pinetum nigrae Em 1978 was described from the region of Baba Mountain (Pelister). The most of diagnostic species could be found also in the high-altitudinal Black Pine forests from West Rhodope and Central Balkan Range like Sesleria latifolia (dominant), Iberis sempervirens, Daphne blagayana. It could be summarized that the association described by Em (1978) is distributed in the Central Balkans and probably the distribution in Baba (Pelister) Mt. is on the periphery of its range, on the border with Dinaride Mountain System where Pinus nigra subsps. dalmatica occurs. Em (1978) did not give holotypus of the association according to the requirements of ICPN (Weber et al. 2000) but the association was validly described because it was described before 01.01.1979. Two cluster groups (see Figure 2) from Erico-Pinetea from Bulgaria could be accepted as a part of this association in a broad sense of meaning. But the communities on the southern slopes of Central Balkan Range are closer to described from Em (1978) association than these ones from Rhodope Mts. which are geographically closer. It is the reason to describe the high-altitudinal Rhodopean Black Pine forests as a new sub-association while the Central Balkan group is accepted as belonging to the typical subassociation. This syntaxonomic decision will expand the range of described association from Em (1978) to the north and east direction.

\section{Association Seslerio latifoliae-Pinetum nigrae Em 1978 subass. typicum (Table 2)}

Diagnostic species for the association: Pinus nigra subsp. pallasiana (100\%), Sesleria latifolia (96\%), Iberis sempervirens (40\%), Daphne blagayana (24\%).

Constant species: Pinus nigra subsp. pallasiana (100\%), Ostrya carpinifolia (100\%), Sesleria latifolia (96\%), Fagus sylvatica (88\%), Fragaria vesca (84\%), Abies alba subsp. alba (76\%), Cotoneaster nebrodensis (68\%), Acer pseudoplatanus (64\%), Euphorbia amygdaloides (60\%), Acer hyrcanum subsp. hyrcanum (56\%), Galium schultesii (52\%), Calamagrostis arundinacea (52\%). 
These communities (Figure 8) are distributed on the southern macro-slopes of Central Balkan Range and geographically fall in the Tryoan part of Central Balkan National Park. They are distributed in the altitudinal belt between 1100 and $1500 \mathrm{~m}$, on slopes mostly with west or east exposition. The inclination varies between 5 and $70^{\circ}$, but mostly the terrains are steep $-40-50^{\circ}$. The canopy varies between $50-80 \%$, (mostly $60-70 \%$ ).

The Black Pine (Pinus nigra subsp. pallasiana) is mostly co-dominant together with Common Beech (Fagus sylvatica), European Hop-Hornbeam (Ostrya carpinifolia) and European Silver Fir (Abies alba subsp. alba). The tree layer includes also species like Acer hyrcanum, A. pseudoplatanus, Fraxinus ornus. The shrub layer is typical for the terrains with rocky outcrops and includes species like Genista rumelica, Cotoneaster nebrodensis, Daphne mezereum, etc. The herbaceous layer is also rich and includes mostly species typical for coniferous and beech forests like Calamagrostis arundinacea, Luzula sylvatica, Mycelis muralis, Doronicum columnae, Cephalanthera rubra, Galium schultesii, Laserpitium siler. The diagnostic species like Sesleria latifolia is a dominant. Also the other diagnostic species for the association like Iberis sempervirens, Daphne blagayana are also well represented in a part of communities. They also emphasized the relict origin of Black Pine communities survived on the steep and rocky places surrounded by the dominant Common Beech forests.

\section{Association Seslerio latifoliae-Pinetum nigrae Em 1978} subass. haberletosum rhodopensis subass. nova hoc loco (Table 2) holotypus rel. 33.

Diagnostic species for the subassociation: Pinus nigra subsp. pallasiana (100\%), Haberlea rhodopensis (24\%), Cotoneaster integerrimus (38\%).

Constant species: Pinus nigra subsp. pallasiana (100\%), Calamagrostis arundinacea (92\%), Hieracium murorum gr. (81\%), Euphorbia amygdaloides (73\%), Abies alba subsp. alba (65\%), Aremonia agrimonoides (62\%), Acer hyrcanum subsp. hyrcanicum (58\%), Primula veris (58\%), Mycelis muralis (58\%), Tanacetum corymbosum (58\%), Picea abies (62\%), Salvia glutinosa (58\%), Physospermum cornubiense (54\%).

This syntaxon was described from West Rhodope Mts., especially from Kazanite and Kastrakli Reserves, on the altitudinal belt between 1000-1300 m. Typical are the very steep slopes, mostly about $50^{\circ}$, with not very big tree

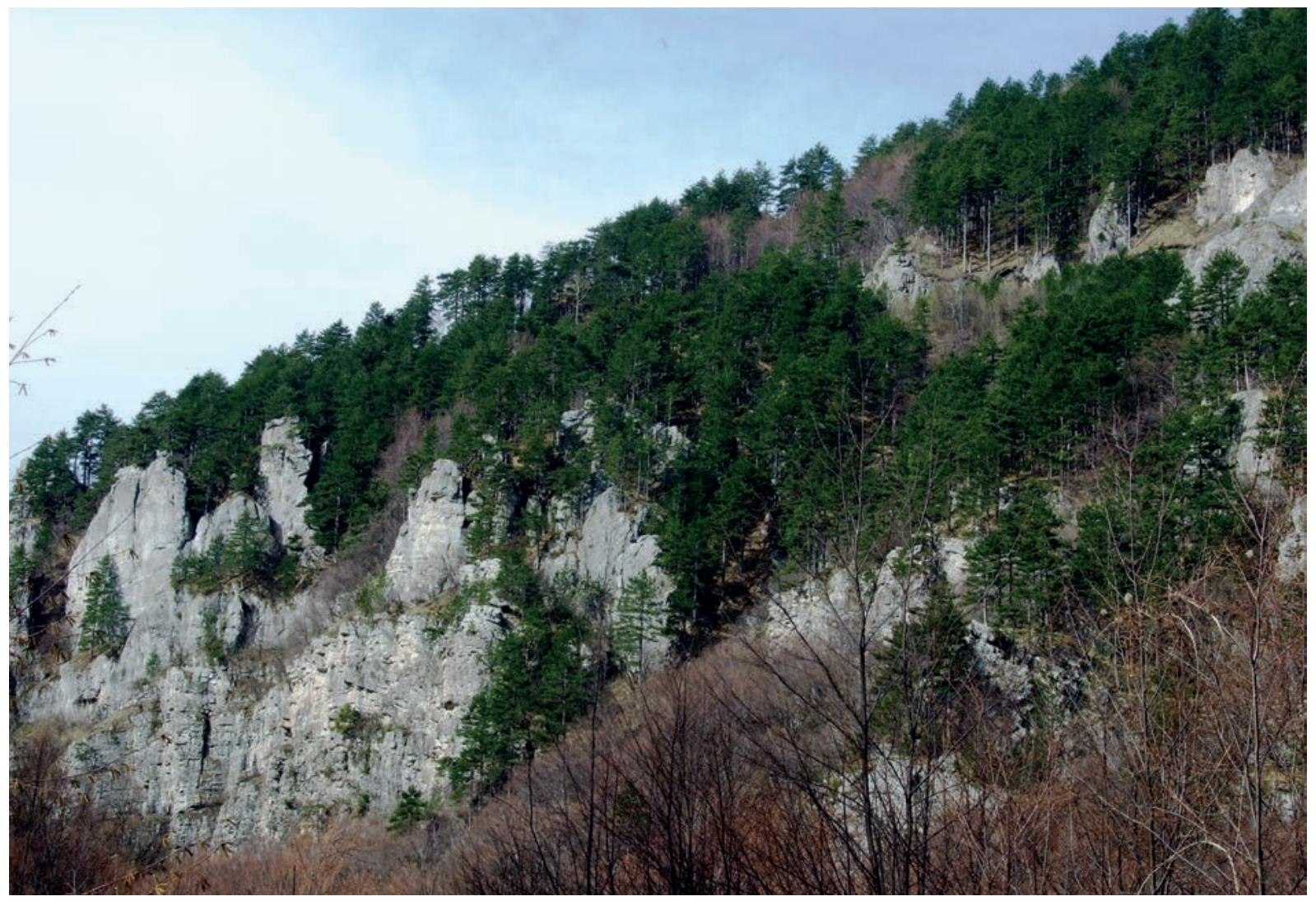

Figure 8: Stand of the association Seslerio latifoliae-Pinetum pallassianae in Central Balkan Mts., Ortaburun Locality. Photo: Ivajlo Nikolov. Slika 8: Sestoj asociacije Seslerio latifoliae-Pinetum pallassianae v gorovju Srednji Balkan, območje Ortaburun. Foto: Ivajlo Nikolov. 
canopy (50-60\%) because of the great calcareous rocky outcrops. The exposition varies from mostly northern in Kazanite Reserve to mostly southern in Kastrakli Reserve.

Black Pine forests unlike to these from Central Balkan are surrounded mainly from coniferous forests dominated by the Spruce (Picea abies). It affects also to their floristic composition and ecological structure. Pinus nigra is not a clear dominant but co-dominant with Abies alba and $\mathrm{Fa}$ gus sylvatica. The last one increases in the understory. The species composition of heathland and herbaceous layers is determined from the dominants like Vaccinium myrtillus, Calamagrostis arundinacea, Luzula luzuloides and also Sesleria latifolia. The last species is not so common like to Central Balkan Range and dominates mostly in Kastrakli Reserve. Typical is that the ecological and floristic structure is a mixture between thermophilous species from the oak forests and more mesophilous typical for Beech and Spruce and Fir coniferous forests. The first group includes species like Fraxinus ornus, Chamaecytisus hirsutus, Tanacetum corymbosum, Physospermum cornubiense, Festuca heterophylla, etc. The second group includes species like Aremonia agrimonoides, Luzula luzuloides, Dryopteris filixmas, Oxalis acetosella, and Orthilia secunda.

This group of communities was separated as the new subassociation haberletosum. Both differential species: Haberlea rhodopensis and Cotoneaster integerrimus are chasmophytes and emphasize the very steep and rocky substrates occupied from the Black Pine communities. Haberlea rhodopensis is also Tertiary relicts with a limited distribution in the mountains in the central part of Balkan Peninsula.

\section{Pinus nigra subsp. pallasiana and Brachypodium pin- natum community (Table 2 )}

Constant and dominant species: Pinus nigra subsp. pallasiana (100\%), Pinus sylvestris (50\%), Brachypodium pinnatum (75\%).

Four relevés of Black Pine communities from West Rhodope Mts. are determined only as communities because lack of sufficient material to be classified. They are dominated from Pinus nigra subsp. pallasiana, and in three of them Brachypodium pinnatum is a dominant in the herbaceous layers. But their floristic composition is too heterogeneous and allows only to being included in Fraxino orni-Pinion nigrae Em 1978 and Erico-Pinetea. The common species in all communities are widespread in different forest types - such are Primula veris, Dactylis glomerata, Euphorbia amygdaloides, Cruciata glabra. The community from Chervenata Stena Reserve includes also the Balkan endemic Pulsatilla halleri subsp. rhodopaea which is part of species complex diagnostic to the class Erico-Pinetea. Future investigations will decide where is the place of these or similar to them forest communities which are widespread in many places in the Bulgarian mountains.

\section{Discussion}

As a conclusion we can summarise some common feature in all described Black Pine communities in Bulgaria. Everywhere they are fragments of older (relict) vegetation. Well-preserved parts of the relict forests that are with preserved composition and structure of the autochthonous vegetation are very rare. Apart from the autochthonous communities also secondary ones exist. They occur in the three climatic zones in Bulgaria: moderate continental, transitional and continental-Mediterranean. They inhabit steep slopes mainly with southern aspect. The Black Pine forests prefer alkaline rocks but in Rhodope Mts. they can occur also on other types of bedrock. The Black Pine is rarely clear dominant but often forms mixed communities with various coniferous and deciduous tree species that have xerothermic or meso-xerothermic characteristics. But the natural habitats of the species have been strongly reduced. The forests have been destroyed as a result of various economic activities (including unregulated logging) or have been replaced by Quercus dalechampii, Fagus sylvatica, etc. as a result of natural successions. Parts of the communities have been turned into open (sparse) forests (Roussakova \& Valchev 2015).

Everywhere in its natural range, the Black Pine communities are usually small, relict and isolated inside the dominant forest types. The last ones could be coniferous forests from Vaccinio-Piceetea in the mountains, or deciduous forests from Quercetea pubescentis, Quercetea robori-petraeae or Carpino-Fagetea (depending from the altitude and latitude), or even evergreen from Quercetea ilicis in the southernmost parts of this range. It is the main reason for describing of many Black Pine associations usually with small areas everywhere in the species range. This situation is repeating in all neighbouring of Bulgaria countries where this subspecies occurs. But it is also the same with the communities of other subspecies like Pinus nigra subsp. dalmatica, Pinus nigra subsp. banatica, Pinus nigra subsp. calabrica, Pinus nigra subsp. salzmanii, etc. (see Trinajstić 1986, 1998, 1999, Regato et al. 1995, Dring et al. 2002, Brullo et al. 2001, Zupančič 2007, Sedlar et al. 2011, Coldea 2015, etc.).

In former Yugoslavia the subspecies Pinus nigra subsp. pallasiana appear in communities in the southern and eastern parts of FYR Macedonia and Eastern Serbia (Horvat 1959, Em 1962, Horvat et al. 1974, Škorić \& Vasić 2006, etc.). Besides the association Seslerio latifoliae-Pinetum nigrae, Em (1978) has described also 
the associations Lathyro versicoloris-Pinetum nigrae and Pulsatillo macedonicae-Pinetum nigrae. But they are with limited geographical distribution.

In Serbia, the subspecies is located only in the eastern part of the country - the valleys of Resava, Jerma and Lazareva Rivers, Suva, Ducat and Crnook Mts. (Avramović et al. 2006). In the last one is located the single reserve (Jarešnik) of Palla’s Black Pine forests in the country (see Ostoić \& Jovanović 2008). But there are not really validly published associations from the country, which can be compared with the neighbouring similar in Bulgaria. The associations Seslerio-Pinetum pallasianae N. Rand et al. 2006, Vaccinio-Pinetum pallasianae N. Rand et al. 2006, published and cited also by Milosavljević et al. (2008), are "nomen nudum". Not valid is also the association Taxo-Pinetum nigrae Mišić 1981 and it was correctly cited as a community from Ostoić \& Jovanović (2008). The indirectly cited floristic structure of these communities indicated their closer similarity to Erico-Pinetea, than to Quercetea pubescentis, but for more precise comparison releves are necessary to be availible. The syntaxa described in East Serbia also include two associations with very limited distribution: Humileto-Pinetum nigrae Jovanović 1956 and Colurno-Pinetum nigrae Jovanović 1951. According to Tatić \& Tomović (2006) both last mentioned syntaxa belong to one association - Carici humilis-Pinetum nigrae B. Jovanović 1956 from Suva Mt. and Sukovska Reka locality. The diagnostic species of the association were not indicated, but the floristic structure and ecological and geographical peculiarities have proved that it is another and different syntaxon with many diagnostic for class Festuco-Brometea species like Carex humilis, Sesleria filifolia, Galium purpureum, Achillea clypeolata, Melica ciliata, etc.

The presence of Pinus nigra subsp. pallasiana in Romania according to Boşcaiu \& Boşcaiu, (1999) is located only in south-westernmost part of the country. The single described association Genisto radiatae-Pinetum pallasianae (Fekete 1959) Resmerița 1972 has the diagnostic species Genista radiata, G. januensis, Festuca xanthina, Linum uninerve and Campanula kladniana. According to Coldea (2015) it is included in the alliance Seslerio rigidae-Pinion sylvestris Coldea 1991 together with the surrounding forests dominated from Pinus sylvestris. This alliance and communities does not occur in the geographical region of Bulgaria.

The forests of Pinus nigra subsp. pallasiana are represented from one association in Ukraine only in southeastern part and the Crimean Peninsula (Didukh 2003). But it is very specific and separated in different alliance and even order Pinetalia pallasianae-kochianae Korzhenevsky 1998 (see Mucina et al. 2016) also enoughly different from the Balkan communities.
The ecology and classification of the forests of Pinus nigra subsp. pallasiana in Greece is discussed in several publications (see Barbero \& Quezel 1976, Bergmeier 1990, 2002, Dimopoulos \& Georgiadis 1995, Dimopolous et al. 1996, Brullo et al. 2001, etc.). For example, Bergmeier (1990) has corrected some of syntaxa described by Barbero \& Quezel (1976) which were not described in accordance of the Code of phytocoenolical nomenclature like the associations Pinus nigra subsp. pallasiana and Campanula stenosiphon community, Pinus nigra subsp. pallasiana and Crataegus pycnoloba (both from Pelopones), Pinus nigra subsp. pallasiana and Staehelina uniflosculosa, Pinus nigra subsp. pallasiana and Daphne blagayna (both from Pelagonia) and Pinus nigra subsp. pallasiana and Sorbus torminalis (from Pindus Mt.). The most of them were assigned to Abieto-Pinion, now Abietion cephalonicae Hovat et al. 1974 - determined by Mucina et al. (2016) as relict supramediterranean Hellenic fir and Black Pine forests. In spite of sometime similar ecological and floristic structure of these communities to the Bulgarian Black Pine forests they belong to the typical oro-mediterranean forest vegetation.

The last conception is especially the association Seslerio robustae-Pinetum pallasianae from Kato Olimbos to be included in the alliance Chamaecytiso hirsuti-Pinion pallasianae Barbero et Quézel 1976 (Mucina et al. 2016). Such communities from Peloponissos (South Greece) are represented from two associations (see Dimopoulos et al. 1996). The associations Cicero graeci-Pinetum pallasianae Dimopolous et al. 1996 is a part of evergreen vegetation from Quercetea ilicis, while the association Crataego pycnolobae-Pinetum pallasianae Barbero \& Quezel 1976 represents xerophilous decidouous forests from Quercetea pubescentis but the relict supramediterranean alliance Abietion cephallonicae Horvat et al. 1974. The association Pyrolo chlorantae-Pinetum nigrae from Mt. Parnon (Peloponissos) also is within Abietion cephalonicae (Bergmeier 2002) which alliance does not occur in Bulgaria.

Very complicated is the situation in Turkey, where the subspecies Pinus nigra subsp. pallasiana is widespread and participates in many different syntaxa, which have been summarized mainly in the work of Ketenoğlu et al. (2010). More than 33 associations have been described there and all of them represent the xerophilous deciduous vegetation of Quercetea pubescentis (see Akman et al. 1979, Quézel et al. 1980, etc) but within special for Asia Minor alliances and even orders. The taxon Pinus nigra subsp. pallasiana is mostly distributed in Northern (Pontic Mountains, the provinces of Kastamonu, Samsun, Sinop, Bolu and Cankiri), Western (the provinces of Kutahya, Ankara, Afyon, Eskisehir, etc.) and sporadic in the Central Part (Konya, Aksaray). The as- 
sociations from Pontic Mountains belong to the specific order Querco cerridis-Carpinetalia orientalis Quézel et al. 1980 and the alliances Carpino betuli-Acerion hyrcani Quézel et al. 1978, Cisto laurifolii-Pinion pallasianae Akman et al. 1978, Quercion anatolicae Akman et al. 1979. These ones from the western and central parts belong to another order Querco pseudocerridis-Cedretalia libani Barbéro et al. 1974 and its alliances Abieto cilicicae-Cedrion libani Quézel et al. 1978, Lonicero nummulariafoliae-Cedrion libani Quézel et al. 1978, Ostryo carpinifoliae-Quercion pseudocerridis Quézel et al. 1978 and Adenocarpo complicati-Pinion pallasianae Quézel et al. 1978. Additional fact which limits any comparisons of these communities of Black Pine to those of the central Balkans is that many of these associations have not been described according to the rules of the ICPN (Weber et al. 2000) (for example Art. 3 (d, h), Art. 5, etc.), therefore they are not valid. Such associations for example are Pinus nigra subsp. pallasiana-Quercus petraea subsp. iberica Akman et al. 1983, Tanaceto-Pinetum nigrae Ozen \& Kilinc 1995, Pinus nigra subsp. pallasianaAstragalus listonia Kilinc 1985, Cephalanthero-Pinetum nigrae Ocakverdi \& Cetik 1987, Pinus nigra subsp. pallasiana-Ligustrum vulgare Akman et al. 1983, Pinus nigra subsp. pallasiana-Anthyllis vulneraria Akman \& Aydogdu 1986, etc. Some of them also are only on the level of community. But it is undeniable that their syntaxonomical position based on the floristic structure and ecological peculiarities is very different comparing with the Black Pine communities in Bulgaria and the Balkans, in general.

The main conclusion from the analysis is that the Black Pine forests in Bulgaria are enough specific to be new syntaxa or to expand the range of distribution of some already described associations, endemic to parts of the Balkans. It emphasizes their significance not only as relict communities with limited distribution but also as important part of the natural vegetation. According to Roussakova \& Valchev (2015) the Black pine forests are also an important edaphic and hydrological factor and also some rare and protected plants occur in them. Such species are Anthemis rumelica, Carduus thracicus, Fritillaria pontica, Pulsatilla halleri subsp. rhodopaea, Scabiosa rhodopensis, Verbascum roripifolium, V. rupestris, Centaurea achtarovii, Kernera saxatilis, etc.

The natural communities of Black Pine in Bulgaria also have conservation significance because as a part of the habitat $9530 *$ (Sub-) Mediterranean pine forests with endemic black pines, they are target object of NATURA 2000 network in Bulgaria. Therefore, their preservation is not only from national Bulgarian but also from European interest.

\section{Acknowledgements}

We want to express our thankfuls to Mr. Ivaylo Ivanov from BSPB for the technical support and also to Dr. Gordana Tomović from Belgrade University and Prof. Vladimir Randjelović from the Univeristy of Niš for the provided literature sources. Part of these studies were made during the implementation of project BG161PO005/11/3/3.2/25/06 "Implementation of activities for organization and management of parks and reserves - Elaboration of management plans of the reserves "Vulchi dol", "Boraka", "Borovec", "Zhenda" and "Chamluka".

\section{References}

Akman, Y., Barbéro, M. \& Quézel, P. 1979: Contribution to the study of forest vegetation of Mediterranean Anatolia. Phytocoenolgia 5: 189-276.

Aksoy, A. \& Gemici, Y. 2010: Studies on forest vegetation of Mahmut mountain of Izmir in Turkey. J. Environ. Biol. 31: 101-108.

Apostolova, I. \& Slavova, L. 1997: Compendium of Bulgarian plant communities published during 1891-1995. Sofia, 340 pp. [in Bulgarian].

Avramović, D., Milosavljević, V., Vilotiević, M. \& Ranđelović, N. 2006: The horology and ecology of Pinus pallasiana in Serbia. - In: II International Symposium of ecologists of Montenegro - Proceeding of the symposium: 73-75.

Barbéro, M. \& Quézel, P. 1976: Les groupements forestiers de Grèce centro-méridionale. Ecol. Medit. 2: 3-86.

Bergmeier, E. 1990: Wälder und gübusche des niederen Olymp (Kato Olimbos, NO-Thessalien). Ein beitrag zur systematischen und orographischen vegetationsgliederung Griechenlands. Phytocoenologia 18: 161-342.

Bergmeier, E. 2002: Plant communities and habitat differentiation in the Mediterranean coniferous woodlands in Mt. Parnon (Greece). Folia Geobotanica et Phytotaxonomica 37: 309-331.

Bondev, I. 1991: The vegetation of Bulgaria. Map in scale 1:600000 with explanatory text. Publ. House of Sofia University "St. Kliment Ochridsky”, Sofia, 183 pp. [in Bulgarian]

Bondev, I. 2002: Geobotanic regioning. - In: Kopralev I. (ed.): Geography of Bulgaria, physical geography. Socio-economic geography. Publishing House ForCom., Sofia, pp. 336-352. [in Bulgarian]

Bondev, I. \& Lazarov, I. 1995: The vegetation of the Gabra reserve. In: Tsankov, G. (ed.): Proc. Jubil. Symp. on the Centenary of Acad. B. Stephanov, Sofia, June 2-3, 1994. Publishing House Bulg. Acad. Sci., Sofia, vol. 2, pp. 14-18. [in Bulgarian]

Bondev, I. \& Lyubenov, M. 1985: The vegetation communities in the Borovo Reserve in the Eastern Rhodopes. - In: Nedyalkov, S. (ed.): Int. Symp. Proj. 8-MAB. Conservation Nat. Areas \& Genet. Material they Contain, Blagoevgrad, September 23-28, 1985. Publishing House Bulg. Acad. Sci., Sofia, vol. 2, pp. 142-147. [in Bulgarian] 
Bondev, I. \& Lyubenova, M. 1985: The plant cover of the Chamluka reserve in the Eastern Rhodopes. - In: Nedyalkov, S. (ed.): Int. Symp. Proj. 8-MAB Conservation Nat. Areas \& Genet. Material they Contain, Blagoevgrad, September 23-28, 1985. Publishing House Bulg. Acad. Sci., Sofia, vol. 3, pp. 71-79. [in Bulgarian]

Bondev, I. \& Yordanov, D. 1973: Map of the forests (Text and map). - In: Gulubov, J.(ed.): Atlas of PR Bulgaria. Publishing House Bulg. Acad. Sci., Sofia, pp. 85, 90. [in Bulgarian]

Boşcaiu, N. \& Boşcaiu, M. 1999: On the presence of Pinus nigra subsp. pallasiana in Romania. (N.F. 426) Wissenschaftliche Mitt. Niederosterr. Landesmus. 12: 21-24.

Braun-Blanquet, J. 1964: Pflanzensoziologie. Grundzuge der Vegetationskunde. Springer-Verlag, Wien and New York, p. 865.

Brower, J., Zar, J. \& von Ende, C. 1998: Field and laboratory methods for general ecology. $4^{\text {th }}$ ed. WCB/McGraw-Hill, p. 273.

Brullo S., G. Giusso del Galdo \& Guarino, R. 2001: The orophilous communities of the Pino-Juniperetea class in the Central and Eastern Mediterranean area. Feddes Repertorium 112 (3-4): 261-308.

Coldea, G. 2015: Classe Erico-Pinetea. In: Coldea, G. (ed.). Les associations vegetales de Roumanie. Tome 3. Les associations forestrieres et arbustives. Presa Universitara Clujeana \& Accent, pp. 189-192.

Coldea, G. (ed.). 2015: Les associations vegetales de Roumanie. Tome 3. Les associations forestrieres et arbustives. Presa Universitara Clujeana. \& Accent.

Debazac, E. 1970: Contibution a l' Etude de la répartition et de l' Ecologie de Pinus nigra en Grèce. Fonds Special des Nations Unies, project UNSF/FAO/GRE 20/230. L' Institut De Recherches Forestieres, Athènes, p. 20.

Debazac, E. 1971: Contibution a la connaissance de la répartition et de l' écologie de Pinus nigra Arn. dans la Sud-Est de l'Europe. Ann. Sci. Forest. 28(2): 91-139.

Delipavlov, D., Cheshmedzhiev, I., Popova, M., Terziiski, D. \& Kovachev, I. 2003: Determination Handbook of the plants in Bulgaria. Academic Publishing House of the Agricultural University, Plovdiv, p. 591. [in Bulgarian]

Didukh, Y. 2003: Mountain forests (Erico-Pinetea Horvat 1959). Vegetation of Ukraine. Ukrainian coniferous forests. - In: Proceedings of Rob. Meeting, Kyiv, November 2003, pp. 43-79. [in Ukrainian]

Dimopoulos, P. \& Georgiadis, T. 1995: Present state of the phytosociological research on the Greek mountains, syntaxonomy and future perspectives. Annali di Botanica 53: 119-133.

Dimopoulos, P., Georgiadis T. \& Sykora, K. 1996: Phytosociological research on the montane coniferous forests of Greece: Mount Killini (NE Peloponnisos - S. Greece). Folia Geobotanica et Phytotaxonomica 31: 169-195.

Domac, R. 1965: Die Wälder der dalmatischen Schwarzföhre (Pinus nigra Arn. subsp. dalmatica Vis. s.l.) in Jugoslawien. Ber. Geobot. Inst. ETH, Stift. Rübel, Zürich 36: 103-116.

Dring, J., Hoda, P., Mersinllari, M., Mullai, A., Pignatii, S. \& Rodwell, J. 2002: Plant communities of Albania - a preliminary overview. Annali di Botanica 2: 7-30.

Em, H. 1962: Coniferous forest vegetation in People's Republic of Macedonia. Biol. Glasn., Skopje 15: 1-38. [in Serbo-Croatian]
Em, H. 1978: About some characteristics of the Pine forests in Macedonia I. The relict Black Pine communities. Poročila Vzhodnoalp.-dinar. dr. preuč. veget., Ljubljana 14: 129-145. [in Serbo-Croatian]

Gaussen, H., Heywood, V. \& Charter, A. 1993: Pinus L. - In: Tutin, T., Heywood, V., Burges N., Valentine, D., Walters, S. \& Webb, B. (eds.): Flora Europaea, vol. 1. Cambridge University Press, Cambridge, pp. $40-44$.

Gorunova, D. \& Kochev, H. 1992: The vegetation of the basin of Chepelarska River (West Rhodopi) III. Fitologiya 42: 48-65. (in Bulgarian)

Gower, J. 1966: Some distance properties of latent root and vector methods used in multivariate analysis. Biometrika 53: 325-328.

Gussev, Ch. \& Tzonev, R. 2015: European Ecological Network NATURA 2000 in Bulgaria. In: Biserkov, V., Gussev, Ch., Popov, V., Hibaum, G., Roussakova, V., Pandurski, I., Uzunov, J., Dimitrov, M., Tzonev, R. \& Tzoneva, S. (eds.): Red Data Book of the Republic of Bulgaria, vol. 3. Natural habitats, MOEW-BAS, Sofia, pp. 34-40.

Gussev, Ch., Vulchev V., Ganeva, A. \& Gyosheva, M. 2005: Flora, vegetation, macromycetes and habitats in the maintained reserve "Gabra" (Vlahina Mt). - In: Chipev, N. \& Bogoev, V. (eds.): Biodiversity, ecosystems and global change. First Scientific Ecological Conference, Sofia, pp. 89-109. [in Bulgarian]

Horn, H. 1966: Measurement of "Overlap" in comparative ecological studies. Am. Nat. 100: 419-424.

Horvat, I. 1959: Sistematic relations of termophylous oak and pine forests. Biol. Glasn. 12: 1-40. [in Croatian]

Horvat, I., Glavać, V. \& Ellenberg, H. 1974: Vegetation Südosteuropas. Gustav Fischer Verlag, Stuttgart, p. 768.

Janssen, J., Rodwell, J., Garcia Criado, M., Gubbay, S., Haynes, T., Nieto, A., Sanders, N., Landucci, F., Loidi, J., Ssymank, A., Tahvanainen, T., Valderrabano, M., Acosta, A., Aronsson, M., Arts, G., Altorre, F., Bergmeier, E., Bijlsma, R.-J., Bioret, F., BităNicolae, C., Biurrun, I., Calix, M., Capelo, J., Čarni, A., Chytry, M., Dengler, J., Dimopoulos, P., Essi, F., Gardfjeil, H., Gigante, D., Giusso del Gaido, G., Hajek, M., Jansen, F., Jansen, J., Kapfer, J., Mickolajczak, A., Molina, J. A., Molnar, Z., Paternoster, D., Piernik, A., Poulin, B., Renaux, B., Schaminee, J. H. J., Šumberova, K., Toivonen, H., Tonteri, T., Tsiripidis, I., Tzonev, R. \& Valachovič, M. 2016: European red list of habitats - Part 2. Terrestrial and freshwater habitats. $44 \mathrm{p}$.

Ketenoğlu, O., Tug, G., Bingol, U., Geven F., Kurt, L. \& Güney, K. 2010: Synopsis of syntaxonomy of turkish forests. J. Environ. Biol. 31: 71-80.

Lavrenko, E. 1959: Main Principles Governing Plant Communities and the Ways of their Investigation. Field Geobotany 1. Moscow, Leningrad, p. 444. [in Russian]

Lazarov, I. 1995: Phytocoenological research on the coniferous forests in Ossogovska Mountain. - In: Tsankov, G. (ed.): Proc. Jubil. Symp. on the Centenary of Acad. B. Stephanov, Sofia, June 2-3, 1994. Publishing House Bulg. Acad. Sci., Sofia, vol. 2, pp. 27-29. [in Bulgarian]

Liber, Z., Nikolić, T., Mitić, B. \& Šatović, Z. 2003: RAPD markers and black pine (Pinus nigra Arnold) intraspecies taxonomy - evidence from the study of nine populations. Acta Societatis Botanicorum Poloniae 72: 249-257. 
Meshinev, T. 1995: Rare plant communities south from Smolyan. - In Tsankov, G. (ed.): Proc. Jubil. Symp. on the Centenary of Acad. B. Stephanov, Sofia, June 2-3, 1994. Publishing House Bulg. Acad. Sci., Sofia , vol. 2, pp. 54-57. [in Bulgarian]

Meshinev, T. 1985: Phytocoenotic characteristic of Kastrakli Reserve. - In: Nedyalkov, S. (ed.): Int. Symp. Proj. 8-MAB Conservation Nat. Areas \& Genet. Material they Contain, Blagoevgrad, September 23-28, 1985. Publ. House Bulg. Acad. Sci., Sofia, vol. 2, pp. 115-123. [in Bulgarian]

Milosavljević, V., Ranđelović, V., Zlatković, B. \& Ranđelović, N. 2008: Phytocenologic diversity of Krajište in Southeastern Serbia. Natura Montenegrina 7(3): 193-204.

Mišić, V. 1981: The forest vegetation of gorges and canyons in Eastern Serbia. Institut za biološka istraživanja "Siniša Stankovič", Beograd, p. 327. [in Serbian]

Mucina, L., Bültmann, H., Dierßen, K., Theurialt, JP., Raus, T., Čarni, A., Šumberová, K., Willner, W., Dengler, J., Gavilán García, R., Chytrý, M., Hájek, M., Di Pietro, R., Iakushenko, D., Pallas, J., Daniëls, F., Bergmeier, E., Santos Guerra, A., Ermakov, N., Valachovič, M., Schaminée, J., Lysenko, T., Didukh, Y., Pignatti, S., Rodwell, J., Capelo, J., Weber, H., Solomeshch, A., Dimopoulos, P., Aguiar, C., Hennekens, S. \& Tichý, L. 2016: Vegetation of Europe: Hierarchical floristic classification system of vascular plant, bryophytes, lichen, and algal communities. Appied Vegetation Science 19(1): 3-264.

Mueller-Dombois, D. \& Ellenberg, H. 1974: Aims and methods of vegetation ecology. John Wiley and Sons: p. 547.

Naydenov, K., Mladenov, I., Alexandrov, A., Naydenov, M., Gyuleva, V., Goudiaby, V., Nikolić, B. \& Kamary, S. 2015: Patterns of genetic diversity resulting from bottlenecks in European black pine, with implications on local genetic conservation and management practices in Bulgaria. European Journal of Forest Research 134: 669-681.

Naydenov, K., Tremblay, F., Fenton, N. \& Alexandrov, A. 2006: Structure of Pinus nigra Arn. populations in Bulgaria revealed by chloroplast microsatellites and terpenes analysis: provenance tests. Biochem. Sys. Ecol. 34: 562-574.

Nikolov, N. \& Nikolov, V. 1984: Preliminary studies on the flora and vegetation of the Chervenata Stena Biosphere Reserve. - In: Velchev, V. (ed.): Modern Theoretical and Applied Aspects of Plant Ecology. Publishing House Bulg. Acad. Sci., Sofia, vol. 1, pp. 198-210. [in Bulgarian]

Ostojić, D. \& Jovanović, B. 2008: Characteristics of Crimean pine (Pinus pallasiana Lamb.) forests in the reserve "Jarešnik" in the district of Bosilegrad. - In: Proceedings of the III Congress of Ecologists of the Republic of Macedonia with International Participation, 06-09.10.2007, Struga. Special issues of Macedonian Ecological Society, Skopje, vol. 8, pp. 86-91.

Panayotov, M. \& Yurukov, S. 2016: Species composition and distribution of mountain coniferous forests in Bulgaria. - In: Panayotov, M., Bebi, P. \& Yurukov, S. (eds.): Mountain coniferous forests in Bulgaria - structure and natural dynamics. University of Forestry, Sofia, pp. 9-41. [in Bulgarian]

Penev, N. 1938: Coniferous vegetation of Plana Mt. Forestry Ideas 7(2): 89-114, 206-224. [in Bulgarian]

Petkov, S. 1921: Coniferous plants in Vitosha and their importance for the forestation. Journal of BAS, Natural and mathematician science 19: 51-96. [in Bulgarian]
Podani, J. 2001: SYN-TAX-pc. Computer Program for Multivariate Data Analysis in Ecology and Systematics. User's Manual. Scientia Publishing, Budapest, p. 53.

Podani, J. \& Schmera, D. 2006: On dendrogram-based measures of functional diversity. Oikos 115: 179-185.

Poldini, L. \& Vidali, M. 1999: Kombinationsspiele unter Schwarzföhre, Weißkiefer, Hopfenbuche und Mannaesche in den Südostalpen. Wissenschaftliche Mitt. Niederöster. Landesmus. 12: 105-136.

Popović, R., Kojić, M. \& Karadžić, B. 1997: Ecological characteristics of six important submediterranean tree species in Serbia. Bocconea 5: 431-438.

Quézel, P., Barbéro, M. \& Akman, Y. 1980: Contribution to the study of forest vegetation of northern Anatolia. Phytocoenologia 8: 365-519

Regato, P., Gamisans, J. \& Gruber, M. 1995: A syntaxonomical study of Pinus nigra subsp. salzmannii forests in the Iberian peninsula. Phytocoenologia 25(4): 561-578.

Roussakova, V., Genova, E. \& Cherneva, Zh. 1991: Phytocoenological and ecological peculiarities of the Bearberry (Arctostaphylos uva-ursi (L.) Spreng.) in some regions of Bulgaria. Fitologiya 39: 33-53. [in Bulgarian]

Roussakova, V. \& Valchev, V. 2015: 36G3 Forests of Black pine (Pinus nigra subsp. pallasiana). - In: Biserkov, V., Gussev, Ch., Popov, V., Hibaum, G., Roussakova, V., Pandurski, I., Uzunov, J., Dimitrov, M., Tzonev, R. \& Tzoneva, S. (eds.): Red Data Book of the Republic of Bulgaria, vol. 3. Natural habitats, MOEW-BAS, Sofia, pp. 353-355.

Škorić, M. \& Vasić, O. (eds.). 2006. Vegatation of Serbia II. Forest communities 2. SANU, Belgrade, p. 369. [in Serbian]

Sedlar, Z. Hršak, V. \& Šoštarić, R. 2011: Numerical and phytosociological analysis of the Junipero sibiricae-Pinetum dalmaticae Domac (1956) 1965. Association and comparison to Mediterranean forests dominated by Pinus nigra Arn. s.l. Sumarski list 135(3-4): $139-152$.

Seibert, P. 1992: Klasse: Erico-Pinetea Horvat 59. - In: Oberdorfer, E. (ed.): Süddeutsche Pflanzengesellschaften. Teil 4 Wälder und Gebüsche. 2. Aufl., Gustav Fischer Verlag, Jena, Stuttgard, New York, pp. $42-52$

Stoyanov, N. 1921: About the vegetation of Ali-Botush. God. Univ. Sofia, Fiz.-Mat. Fakult. 17(2): 1-35. [in Bulgarian]

Stoyanov, N. 1963: Pinus L. - In: Jordanov, D. (ed.): Fl. Reipubl. Popularis Bulgaricae. In Aedibus Acad. Sci. Bulgaricae, Serdicae, vol. 1, pp. 160-166. [in Bulgarian]

Stranski, I. 1921: Vegetation relations in Middle Rhodopi. Bull. Bulg. Acad. Sci. 16(6): 1-59. [in Bulgarian]

Tatić, B. \& Tomović, Z. 2006. Forests of Black and Scotland Pine. - In: Škorić, M. \& Vasić, O. (eds.): Vegatation of Serbia II. Forest communities 2. SANU, Beograd, pp. 127-150. [in Serbian]

Trinajstić, I. 1986: The forests of the Dalmatian black pine - Pinus nigra Arnold subsp. dalmatica (Vis) Franco - in the Mediterranean region of Croatia. Polj. Šum., Titograd, 32(1): 37-48. [Croatian]

Trinajstić, I. 1998: Nomenclatur-Syntaxonomic revision of subMediterranean forests of Black pine (Pinus nigra Arnold) in Croatia. Šumarski list 122: 147-154. [in Croatian] 
Trinajstić, I. 1999: Syntaxonomische Übersicht der Schwarzföhrenwälder (Pinus nigra Arnold s.l.) Kroatiens Wiss. Mitt. Niederösterr. Landesmus. 12: 137-149.

Van den Maarel, E. 1979: Transformation of cover-abundance values in phytosociology and its effects on community similarity. Vegetatio 39(2): 97-114

Van der Maarel, E. \& Franklin, J. (eds.). 2013. Vegetation ecology. $2^{\text {nd }}$ ed. Wiley-Blackwell, Chichester, p. 556.

Vassilev, K. \& Gavrilova, A. 2016: Flora, habitats and vegetation of Chamdzha Managed Reserve, Central Balkan Range. Forest Rev., Skopje 46: 74-87.

Velchev, V. 2002. Characteristic features and regularities in the distribution of the present day vegetation. - In: Kopralev I. (ed.): Geography of Bulgaria, Physical geography. Socio-economic geography. Publishing House ForCom. Sofia, p. 336-351. [in Bulgarian]

Velchev, V., Vasilev, P. \& Indzheyan, A. 1985: The vegetation of Boraka Reserve in East Rhodopi. - In: Nedyalkov, S. (ed.): Int. Symp. Proj. 8-MAB Conservation Nat. Areas \& Genet. Material they Contain, Blagoevgrad, September 23-28, 1985. Publ. House Bulg. Acad. Sci., Sofia, vol. 1, pp. 104-114. [in Bulgarian]
Vlasev, V. 1966: Black Pine forests in Bulgaria: Resumption and management. Zemizdat Publ. House, Sofia, p. 127. [in Bulgarian]

Weber, H., Moravec, J. \& Theurillat, J.-P. 2000: International code of phytosociological nomenclature. $3^{\text {rd }}$ edition. Journal of Vegetation science 11: 739-768.

Westhoff, V. \& van der Maarel, E. 1978: The Braun-Blanquet Approach. In: Whittaker R.H., (ed.): Classification of plant communities. Junk, The Hague, pp. 287-408.

Zahariev, B. 1934: For the natural localities of the coniferous in Osogovska Mt. Izv. Bulg. Bot. Druzh. 4: 10-35. [in Bulgarian]

Zupančič, M. 2007: Syntaxonomic problems of the classes VaccinioPiceetea and Erico-Pinetea in Slovenia. Fitosociologia 44 (2): 3-13. 


\section{Number of releves}

Locality

Author

Data

Latitude

Longitude

Altitude

Exposition

Inclination

Coverage (\%)

Sample plot (sq. m)

\section{$\begin{array}{llllllllllllll}1 & 2 & 11 & 14 & 16 & 13 & 12 & 15 & 80 & 81 & 91 & 93 & 82 & 83\end{array}$}

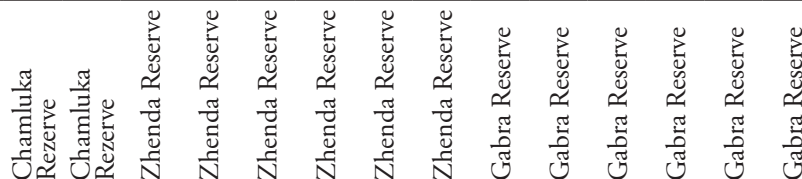

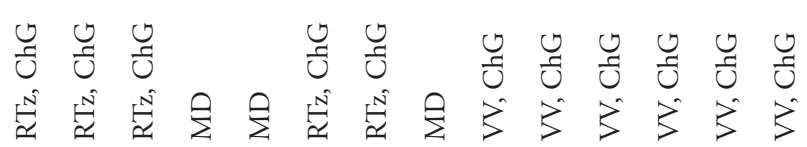

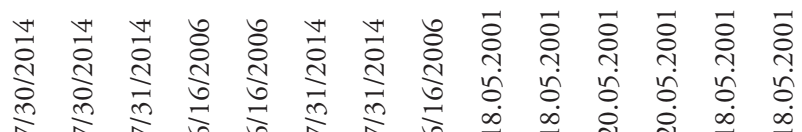

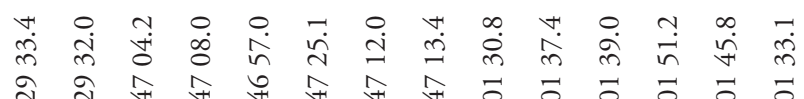

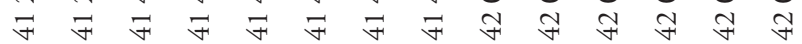

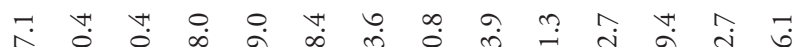

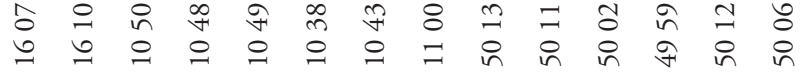

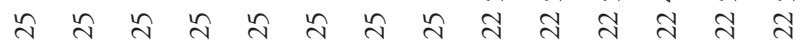

市

$\begin{array}{lllllllllllllll}\text { E } & E & N & N & S & S E & N & N & W & N W & N W & N E & E & N\end{array}$

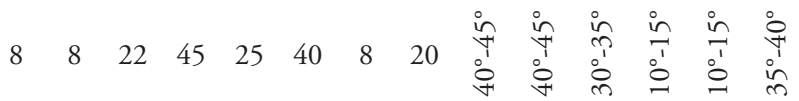

$\begin{array}{llllllllllllll}60 & 60 & 80 & 70 & 70 & 80 & 80 & 70 & 50 & 50 & 60 & 60 & 60 & 80\end{array}$

\& \& \& \& \& \& \& \& \& \&

Association Lathyro laxiflori-Pinetum pallasianae ass. nova, holotypus rel. 11 hoc loco

Pinus nigra J.F. Arnold subsp. palassiana (Lamb.) Holmboe

Aremonia agrimonoides (L.) DC

Lathyrus laxiflorus (Deaf.) Kuntze

Genista carinalis Griseb.

\begin{tabular}{|ccccccccccccccc}
\hline 4 & 4 & 4 & 4 & 4 & 3 & 4 & 4 & 5 & 5 & 5 & 5 & 5 & 5 \\
$2 \mathrm{~b}$ & $\cdot$ & + & + &. & $\cdot$ & + &. &. &. & + &. & + & + \\
$\cdot$ & $\cdot$ & + & + & 1 &. &. & + &. & + & + & + &. &. \\
+ & + & $2 \mathrm{~b}$ & $2 \mathrm{~b}$ & $2 \mathrm{~b}$ & + &. &. & + & + & + & + & & + & \\
\hline
\end{tabular}

Association Junipero deltoidi-Pinetum pallasianae ass. nova, holotypus rel. 47 hoc loco

Juniperus oxycedrus L. subsp. deltoides (R. P. Adams) N. G. Passal. $1 \quad$. 2b . 2b $\quad$ +

Dianthus petraeus Waldst. et Kit. subsp. petraeus

Moehringia pendula (Waldst. et Kit.) Fenzl.

Cotinus cogyggria Scop.

Alliance Fraxino orni-Ostryion Tomazic 1940

Fraxinus ornus L.

Ostrya carpinifolia Scop.

Primula veris L.

Campanula persicifolia L.

Alliance Carpinion orientalis Horvat 1958

Carpinus orientalis Mill.

Order Quercetalia pubescenti-petraeae Klika 1933 and class Quercetea pubescentis Doing-Kraft ex Scamoni et Passarge 1959

Quercus pubescens Willd. 
\begin{tabular}{llllllllllllllllllllllllllllll}
90 & 88 & 84 & 94 & 89 & 92 & 85 & 86 & 87 & $\%$ & 3 & 7 & 4 & 5 & 8 & 6 & 9 & 10 & 47 & 49 & 50 & 48 & 51 & 53 & 52 & 54 & $\%$ \\
\hline
\end{tabular}

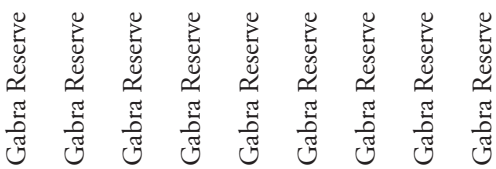

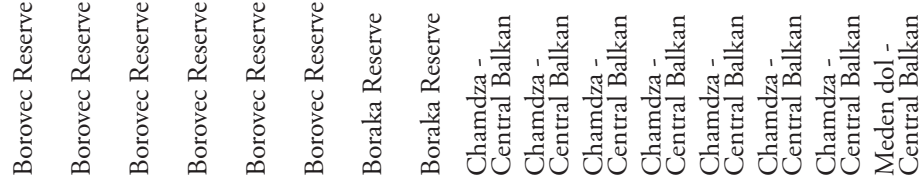
U

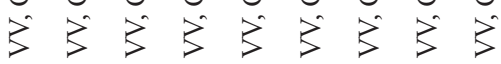

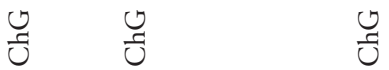

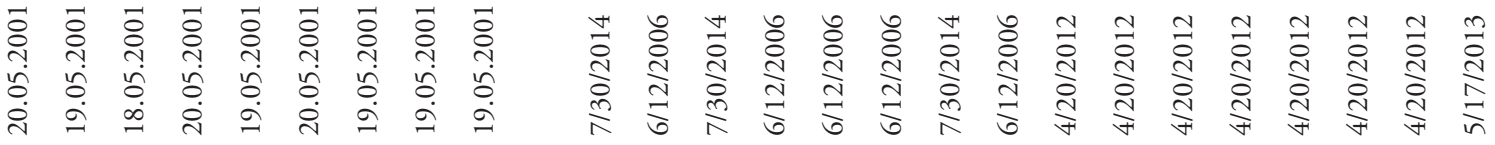

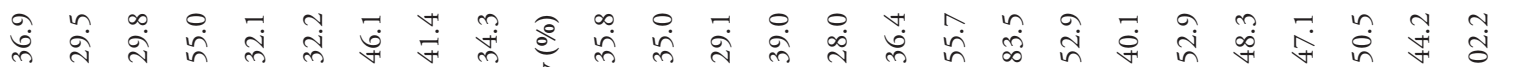

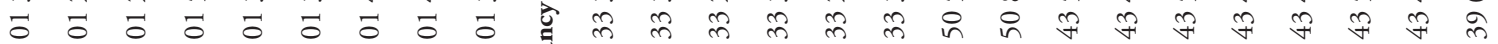
Ұ $尹$ ᄀ

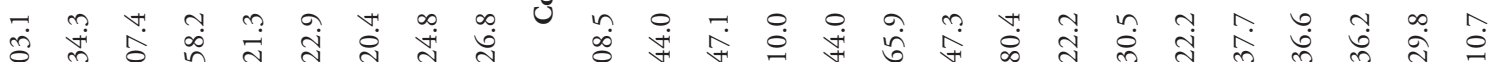

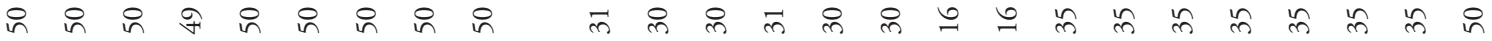
ปี

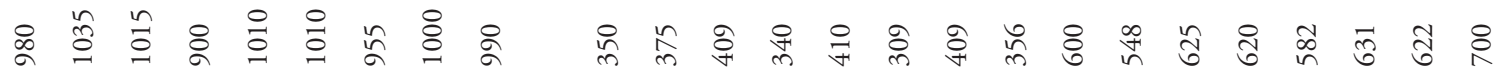
$\begin{array}{lllllllllllllllllllllllll}N W & N & N & N & N W & N E & W & W & W & N W & N E & N & N & N & W & S & S W & S E & S & N & N & E & N E & E & S\end{array}$

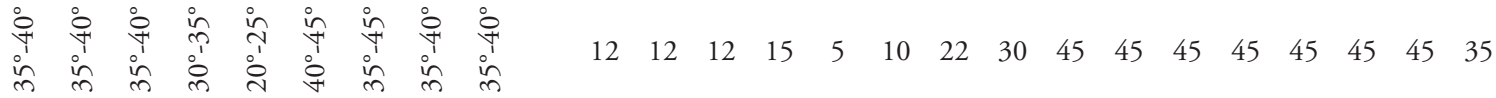
$\begin{array}{llllllllllllllllllllllllll}70 & 80 & 80 & 40 & 50 & 60 & 60 & 60 & 60 & 60 & 60 & 60 & 80 & 80 & 70 & 50 & 50 & 50 & 40 & 60 & 60 & 40 & 60 & 60 & 50\end{array}$

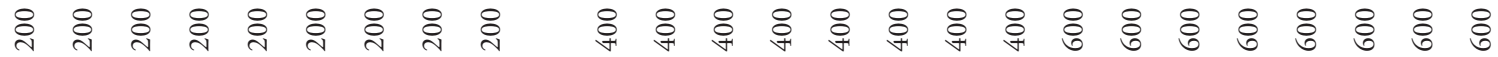

\begin{tabular}{|c|c|c|c|c|c|c|c|c|c|c|c|c|c|c|c|c|c|c|c|c|c|c|c|c|c|}
\hline 5 & 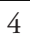 & 5 & 5 & 5 & 5 & 5 & 5 & 5 & 100 & 4 & 3 & 4 & 4 & 5 & 4 & 4 & $2 b$ & $2 b$ & $2 b$ & 3 & 3 & $2 b$ & $2 b$ & $2 b$ & $2 b$ \\
\hline+ & + & . & + & . & + & + & + & r. & 57 & . & . & . & . & . & . & . & . & . & . & . & . & . & . & . & . \\
\hline . & . & + & + & . & . & + & + & . & 48 & . & . & . & . & . & . & . & . & . & . & . & . & . & . & . & . \\
\hline . & . & . & . & . & . & . & . & . & 35 & . & . & . & . & . & $2 \mathrm{~m}$ & + & 1 & . & . & . & . & . & . & & . \\
\hline . & . & . & . & . & . & . & . & 1 & 22 & . & + & + & + & + & . & + & + & $2 b$ & $2 b$ & 1 & 1 & 1 & 1 & $2 b$ & $2 b$ \\
\hline . & . & . & . & . & . & . & . & . & 0 & . & . & . & . & . & . & . & . & 3 & $2 \mathrm{~b}$ & $2 \mathrm{~b}$ & $2 b$ & $2 \mathrm{~b}$ & 1 & $2 \mathrm{~b}$ & . \\
\hline . & . & . & . & . & . & . & . & . & 0 & . & . & . & . & . & . & . & . & $2 b$ & $2 b$ & 3 & 3 & $2 b$ & 3 & 3 & . \\
\hline . & & . & . & . & . & . & . & & 0 & $2 b$ & $2 b$ & 3 & $2 \mathrm{~b}$ & $2 \mathrm{~b}$ & 3 & . & . & . & . & . & . & . & . & . & . \\
\hline
\end{tabular}


Sorbus torminalis (L.) Crantz.

Galium pseudaristatum Schur.

Quercus fraintetto Ten.

Cornus mas L.

Crataegus monogyna Jacq.

Tamus communis $\mathrm{L}$.

Quercus cerris L.

Physospermum cornubiense (L.) DC

Trifolium medium L. subsp. balcanicum Velen.

Tanacetum corymbosum (L.) Sch.Bip.

Clinopodium vulgare $\mathrm{L}$.

Lathyrus niger (L.) Bernh.

Buglossoides purpurocoerulea (L.) I.M.Johnst.

Sorbus domestica L.

Potentilla micrantha Ramond ex DC

Festuca heterophylla Lam.

Acer tataricum L.

Limodorum abortivum (L.) Schwartz.

Pyrus pyraster Burgst.

Helleborus odorus Waldst. et Kit.

Luzula forsteri (Sm.) DC.

Doronicum orientale Hoffm.

Iris sintenisii Janka

Lonicera etrusca Santi.

Pulmonaria mollis Wulfen ex Hornem.

Lathyrus venetus (Mill.) Wohlf.

Silene italica (L.) Pers.

Class Quercetea robori-petraeae Br.-Bl. et Tx. ex Oberd. 1957

Quercus dalechampii Ten.

Euphorbia amygdaloides L.

Chamaecytisus hirsutus (L.) Link.

Quercus petreaea (Mattuschka) Liebl.

Pteridium aquilinum (L.) Kuhn.

Lerchenfeldia flexuosa (L.) Schur.

Class Carpino-Fagetea sylvaticae Jakuch ex Passarge 1968

Melica uniflora Retz.

Poa nemoralis L.

Fagus sylvatica L.

Dactylis glomerata L.

Hieracium gentile Jord. ex Boreau

Sanicula europaea L.

Scilla bifola L.

Viola reichenbachiana Jord. ex Boreau

Galium odoratum (L.) Scop.

Cephalanthera damasonium (Mill.) Druce

Hedera helix L.

Cephalanthera rubra (L.) Rich.

Acer campestre L.

Melittis melissophyllum $\mathrm{L}$.

Luzula luzuloides (Lam.) Dandy 
Mycelis muralis (L.) Dumort.

Prunus avium L.

Carex digitata L.

Campanula rapunculoides $\mathrm{L}$.

Cardamine bulbifera (L.) Crantz.

Epipactis helleborine (L.) Crantz.

Vicia cracca L.

Crataegus pentagyna Waldst. et Kit.

Lilium martagon $\mathrm{L}$.

Lonicera xylosteum L.

Abies alba Mill. subsp. alba

Arum maculatum L.

Carpinus betulus $\mathrm{L}$.

Fraxinus excelsior $\mathrm{L}$.

Neotia nidus-avis (L.) Rich.

Class Vaccinio-Piceetea Br.-Bl. in Br.-Bl. et al. 1939

Juniperus communis L. subsp. communis

Dicranum scoparium Hedw.

\section{Other species}

Veronica chamaedrys L.

Viola odorata L.

Brachypodium sylvaticum (Huds.) P. Beauv.

Stellaria media (L.) Vill.

Rosa canina L.

Peucedanum cervaria (L.) Lapeyr.

Veronica hederifolia L.

Dorycnium herbaceum Vill.

Laser trilobum (L.) Borkh.

Hieracium cymosum $\mathrm{L}$.

Viola tricolor $\mathrm{L}$.

Trifolium alpestre $\mathrm{L}$.

Euphorbia helioscopia L.

Brachythecium velutinum (Hedw.) Schimp.

Hypericum cerastioides (Spach) N. Robson

Micropyrum tenellum Link.

Chamaecytisus absinthioides (Janka) Kuzmanov

Corylus avellana L.

Cruciata glabra (L.) Ehrend.

Fragaria vesca L.

Rosa pimpineifolia L.

Trifolium angustifolium $\mathrm{L}$.

Vicia angustifolia Grufberg

Astragalus depressus L.

Geranium lucidum L.

Lapsana communis $\mathrm{L}$.

Bituminaria bituminosa (L.) Stirt.

Carlina vulgaris L.

Genista tinctoria L.

Geranium sanguineum L.

Poa bulbosa L. 


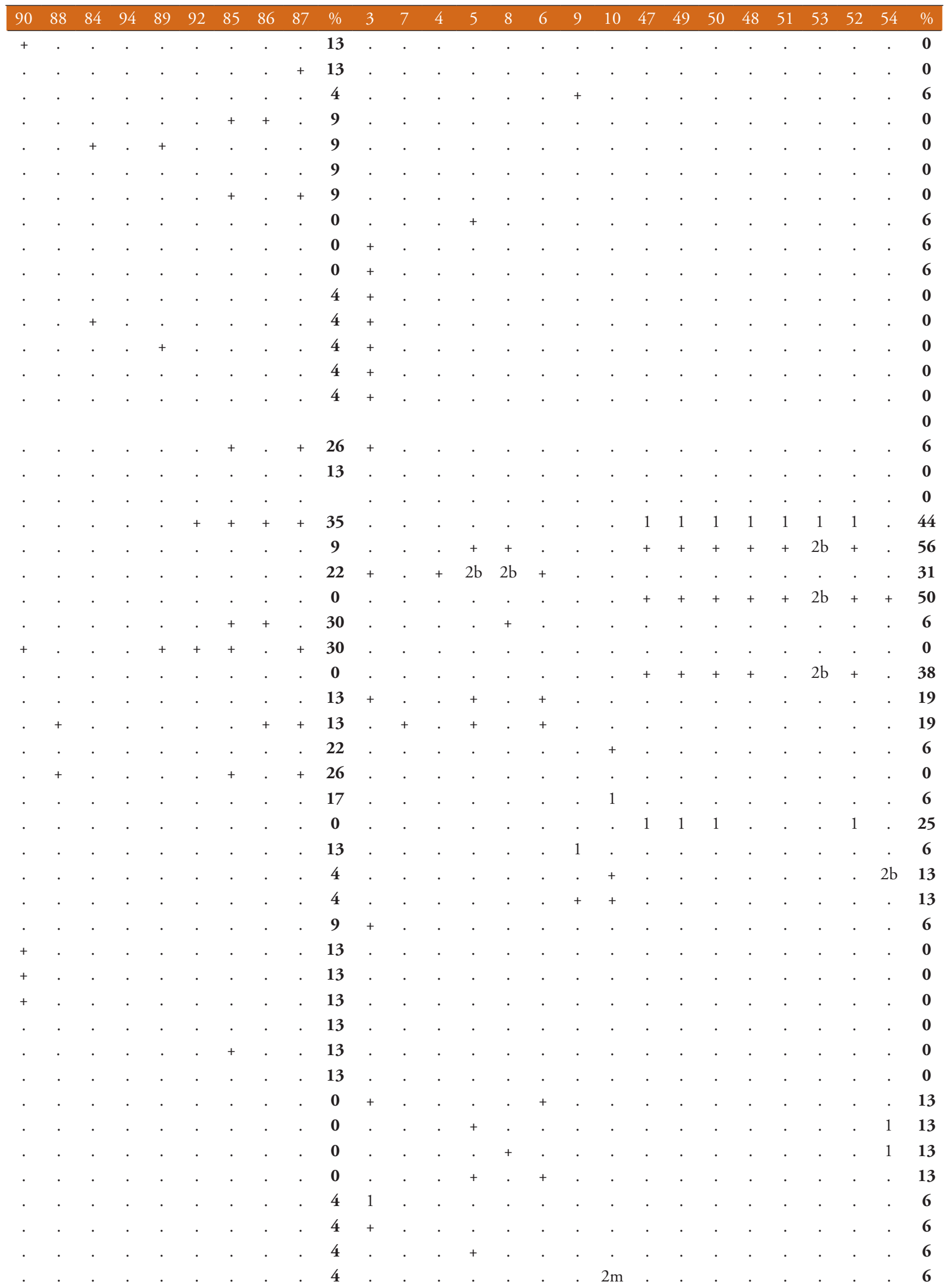




\section{Number of releves}

Prunus cerasifera Ehrh.

Teucrium chamaedrys $\mathrm{L}$.

Thymus sp.

Brachypodium pinnatum (L.) P. Beauv.

Clematis vitalba $\mathrm{L}$.

Galium verum L.

Genista ovata Waldst. et Kit.

Juglans regia $\mathrm{L}$.

Agrimonia eupatoria L.

Ajuga genevensis $\mathrm{L}$.

Anthemis tinctoria L.

Campanula lingulata Waldst. et Kit.

Cardamine hirsuta L.

Clematis viticella $\mathrm{L}$.

Cornus sanguinea L.

Evonymus europaeus L.

Galium aparine L.

Geranium columbinum L.

Geum urbanum L.

Koeleria simonkaii Adamovic

Lamium purpureum L.

Ligustrum vulgare $\mathrm{L}$.

Linara pelisseriana (L.) Mill.

Ophrys cornuta Steven

Parentucellia latifolia (L.) Caruel

Prunus spinosa L.

Ranunculus arvensis $\mathrm{L}$.

Rubus caesius L.

Silene noctiflora L.

Aegopodium podagraria L.

Ajuga reptans L.

Asperula cynanchica L. subsp. cynanchica

Astragalus glyciyhylloides DC.

Calamagrostis arundinacea (L.) Roth.

Chrysopogon gryllus (L.) Trin.

Cladonia foliacea (Huds.) Willd.

Danthonia alpina Vest.

Ferulago sylvatica (Besser) Rchb.

Festuca valesiaca Schleich. ex Gaudin

Filago vulgaris Lam.

Helianthemum nummularium (L.) Mill.

Hieracium hoppeanum Schult.

Hypericum perforatum L.

Hypochaeris maculata L.

Myrrhoides nodosa (L.) Cannon

Populus tremula L.

Silene vulgaris (Moench.) Garcke

Trifolium repens $\mathrm{L}$. 


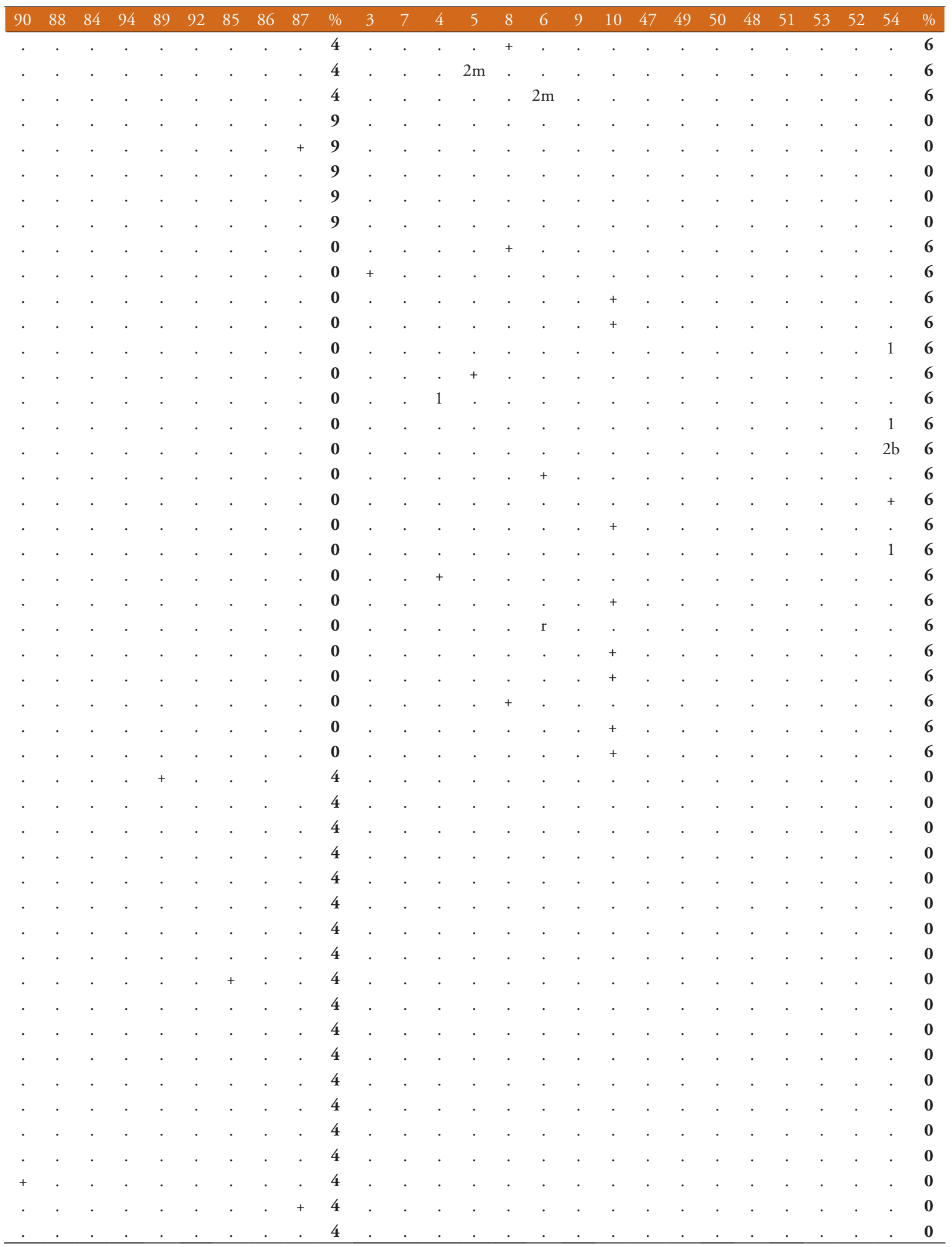


Table 2: Diagnostic table of the syntaxa from Erico-Pinetea.

Tabela 2: Diagnostična tabela sintaksonov razreda Erico-Pinetea.

\section{Number of releve}

Locality

Author

Data

Latitude

Longitude

Altitude

Exposition

Inclination

Coverage (\%)

Sample plot (sq. m)

$\begin{array}{lllllllllllllllllllllll}55 & 57 & 56 & 67 & 68 & 69 & 72 & 73 & 74 & 59 & 58 & 75 & 76 & 78 & 77 & 66 & 70 & 71 & 79 & 60 & 63 & 61 & 62\end{array}$

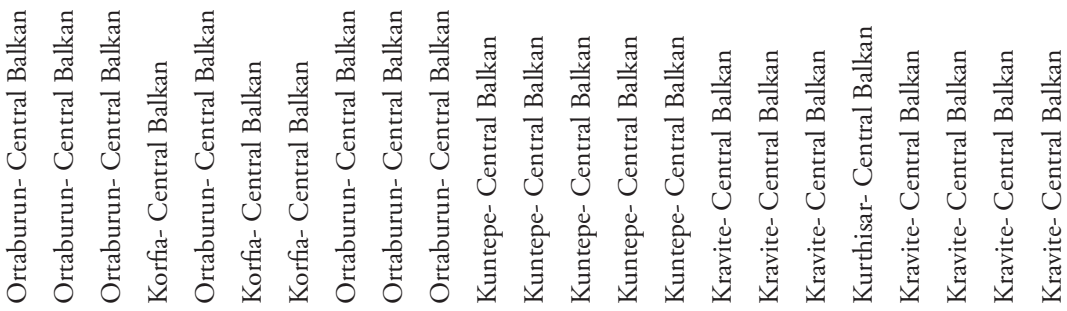

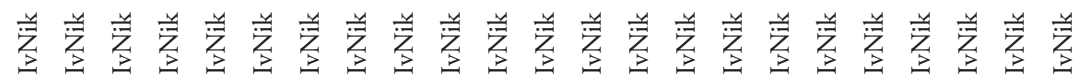

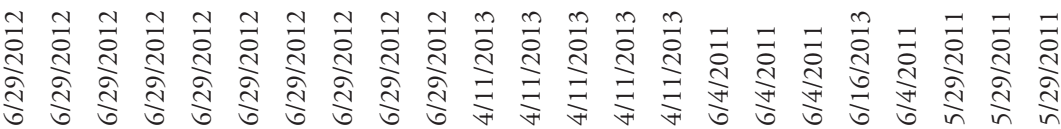

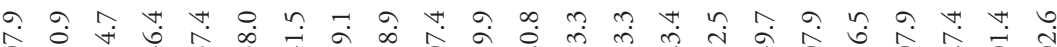

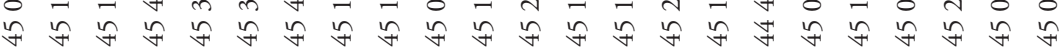

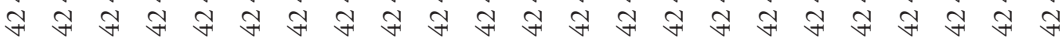

n

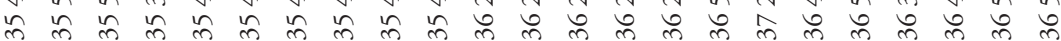

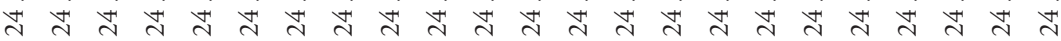

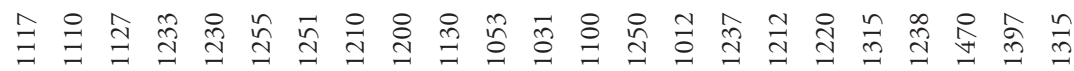

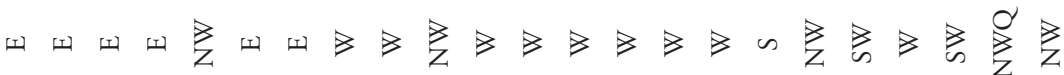

$\begin{array}{lllllllllllllllllllllll}70 & 65 & 50 & 50 & 50 & 50 & 45 & 60 & 60 & 45 & 55 & 40 & 55 & 45 & 45 & 40 & 50 & 50 & 55 & 60 & 30 & 10 & 20\end{array}$

$\begin{array}{lllllllllllllllllllllll}50 & 50 & 70 & 50 & 70 & 70 & 60 & 50 & 50 & 70 & 60 & 60 & 70 & 80 & 50 & 60 & 70 & 70 & 80 & 60 & 60 & 80 & 80\end{array}$

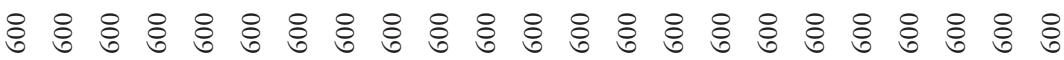

Diagnostic species for association Seslerio latifoliae-Pinetum nigrae Em 1978 subass. typicum

Pinus nigra J.F. Arnold subsp. palassiana

(Lamb.) Holmboe

$\begin{array}{lllllllllllllllllllllll}2 b & 2 b & 3 & 3 & 3 & 2 b & 2 b & 3 & 3 & 2 b & 2 b & 2 b & 3 & 3 & 2 b & 3 & 3 & 3 & 2 b & 3 & 3 & 3 & 3\end{array}$

Sesleria latifolia (Adamovic) Degen

Iberis sempervirens $\mathrm{L}$.

Daphne blagayana Freyer

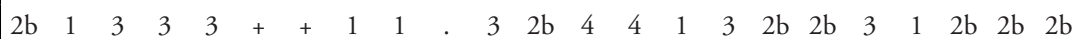

$2 \mathrm{~b} 2 \mathrm{~b}+.2 \mathrm{~b}++11 .+.+. \quad . \quad . \quad 12 \mathrm{~b}$

Differential species for the subassociation haberletosum subass. nova, holotypus rel. hoc loco 33

Haberlea rhodopensis Friv.

Cotoneaster integerrimus Medicus

Pinus nigra subsp. pallasiana and Brachypodium pinnatum community

Brachypodium pinnatum (L.) P. Beauv.

Alliance Fraxino orni-Pinion nigrae Em 1978, order Erico-Pinetalia Horvat 1959 and class Erico-Pinetea Horvat 1959

Ostrya carpinifolia Scorp.

Fraxinus ornus L.

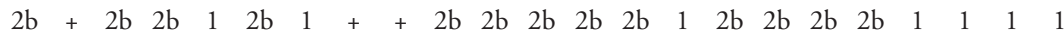

Pinus sylvestris $\mathrm{L}$.

Laserpitium siler $\mathrm{L}$.

Galium lucidum All.

Chamaecytisus hirsutus (L.) Link.

Pulsatilla halleri (All.) Willd. subsp. rhodopaea (Stoj. \& Stefanov) K. Krause

Genista rumelica Velen.

Carex humilis Leyss.

Hieracium pannosum Boiss. 


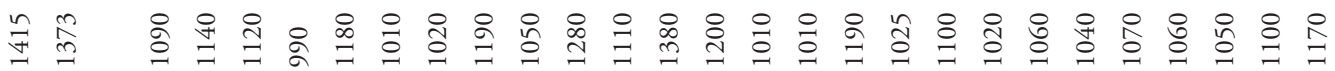
庰总总兽

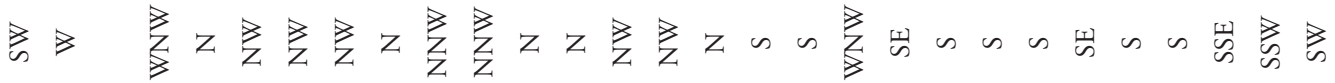
○ 的紫队

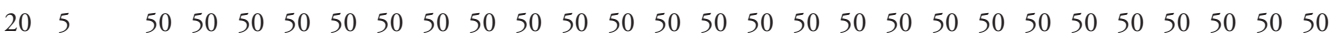

7060
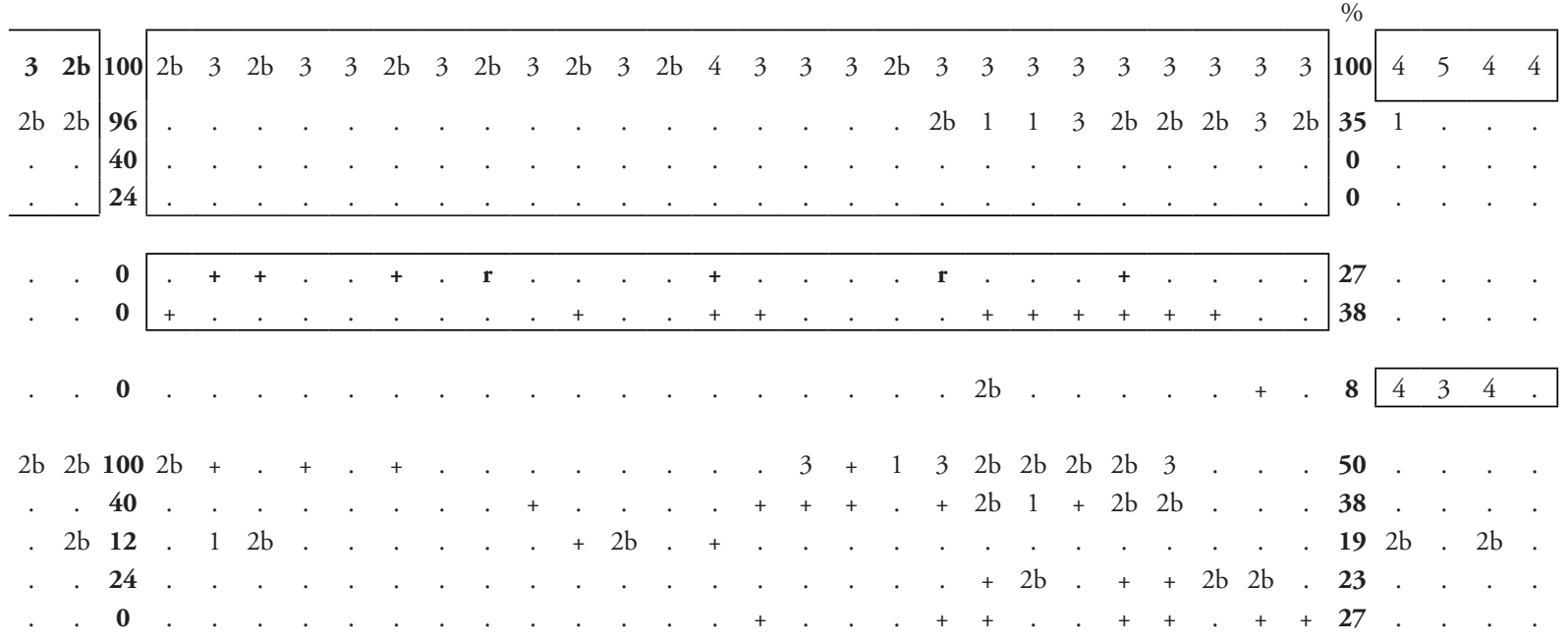
Class Carpino-Fagetea sylvaticae Jakuch ex Passarge 1968

Fagus sylvatica L.

Abies alba Mill. subsp. alba

Hieracium gentile Jord. ex Boreau

Aremonia agrimonodides (L.) DC

Mycelis muralis (L.) Dumort.

Acer pseudoplatanus L.

Prenanthes purpurea $\mathrm{L}$.

Lilium martagon $\mathrm{L}$.

Luzula luzuloides (Lam.) Dandy

Cotoneaster nebrodensis (Guss.) C. Koch

Salvia glutinosa L.

Campanula rapunculoides $\mathrm{L}$.

Galium schultesii Vest.

Hepatica nobilis Mill.

Luzula sylvatica (Hudson) Gaudin

Cephalanthera damasonium (Mill.) Druce

Doronicum columnae Ten.

Poa nemoralis L.

Populus tremula L.

Dryopteris filix-mas (L.) Schott.

Lonicera xylosteum $\mathrm{L}$.

Viola reichenbachiana Jord. ex Boreau

Cephalanthera rubra (L.) Rich.

Symphytum tuberosum L.

Dactylis glomerata L.

Geranium robertianum L.

Sorbus aucuparia L. x Sorbus aria (L.) Crantz.

Daphne mezereum L.

Knautia drymeja Heuff.

Acer platanoides L.

Aquilegia nigricans Baumg.

Hedera helix $\mathrm{L}$.

Lathyrus vernus Bernh.

Campanula trachelium L. subsp. trachelium

Epilobium montanum L.

Galium odoratum (L.) Scop.

Melica nutans L.

Mercurialis perennis $\mathrm{L}$.

Sanicula europaea L.

Sorbus austriaca (Beck) Hedl.

Veronica urticifolia Jacq.

Carpinus betulus L.

Anemone ranunculoides $\mathrm{L}$.

Cardamine bulbifera (L.) Crantz.

Lamium galeobdolon (L.) L.

Prunus avium L.

Athyrium filix-femina (L.) Rothm.

Convallaria majalis $\mathrm{L}$.

Epipactis helleborine (L.) Crantz.

Fraxinus excelsior $\mathrm{L}$.

Pulmonaria officinalis $\mathrm{L}$.

Tilia cordata Mill.

$2 \mathrm{~b} \quad 2 \mathrm{~b} \quad 1 \quad 2 \mathrm{~b} \quad 3++\begin{array}{llllllllllllll}2 \mathrm{~b} & 1 & 2 \mathrm{~b} & 2 \mathrm{~b} & 2 \mathrm{~b} & 2 \mathrm{~b} & 1 & 2 \mathrm{~b} & 2 \mathrm{~b} & 2 \mathrm{~b} & + & 1 & 1\end{array}$

$2 \mathrm{~b}+2 \mathrm{~b} 2 \mathrm{~b}++2 \mathrm{~b} 11+.+2 \mathrm{~b} 12 \mathrm{~b} 2 \mathrm{~b}+. \cdot 2 \mathrm{~b}$

$1 .+2 .+2 b+1$. +2

$111+.1$. 11.

$11+. .5$

$2 \mathrm{~b} \quad 2 \mathrm{~b} \quad 1+\begin{array}{cccc}1 & + & 1 & 1\end{array}$

$+++2 b++$

$3 . .+.+2 b .2 b$

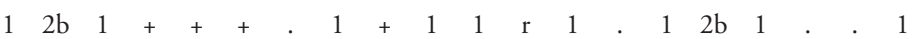

11 1 1

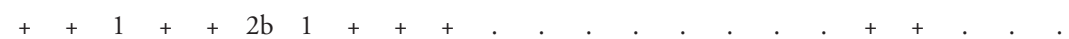

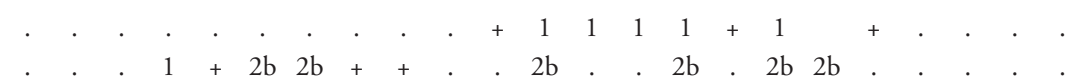

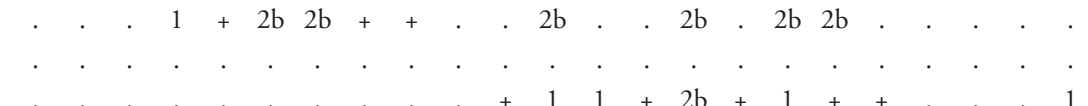




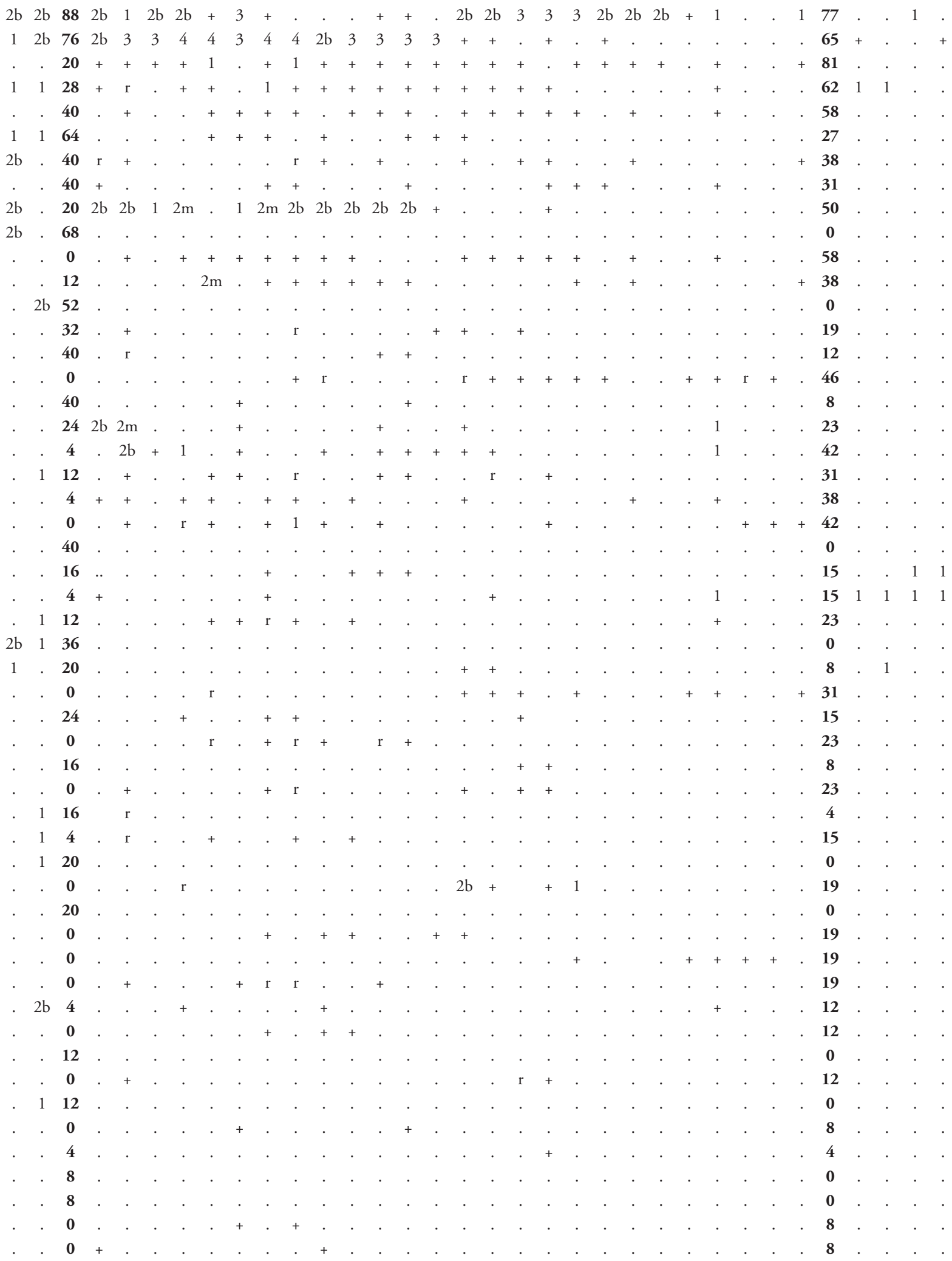


Acer campestre $\mathrm{L}$.

Actaea spicata L.

Anemone nemorosa $\mathrm{L}$.

Arabis procurrens Waldst. et Kit.

Asarum europaeum L.

Festuca drymeja Mert.\& Koch.

Dryopteris carthusiana (Vill.) H. P. Fuchs.

Evonymus latifolius (L.) Mill.

Galium rotundifolium $\mathrm{L}$.

Moehringia trinervia (L.) Clairv.

Myosotis sylvatica Ehrh. ex Hoffm.

Polygonatum latifolium (Jacq.) Desf.

Primula elatior (L.) Hill.

Ranunculus ficaria L. subsp. caltifolius (Rchb.)

Arcang.

Symphytum bulbosum Schim.

Viscum album L.

Class Quercetea robori-petraeae Br.-Bl. et Tx. ex Oberd. 1957

Euphorbia amygdaloides $\mathrm{L}$.

Brachypodium sylvaticum (Huds.) P. Beauv.

Campanula persicifolia L.

Cephalanthera longifolia (L.) Fritsch.

Quercus dalechampii Ten.

Pteridium aquilinum (L.) Kuhn.

Veronica officinalis $\mathrm{L}$.

Lerchenfeldia flexuosa (L.) Schur.

Viburnum lantana $\mathrm{L}$.

Class Vaccinio-Piceetea Br.-Bl. in Br.-Bl. et al. 1939

Picea abies (L) Carst.

Orthilia secunda (L.) House

Vaccinium myrtillus $\mathrm{L}$.

Rosa pendulina $\mathrm{L}$.

Juniperus communis L. subsp. communis

Oxalis acetosella $\mathrm{L}$.

Lonicera caerulea $\mathrm{L}$.

Moneses uniflora (L.) A.Gray

Corallorhiza trifida Chatel

Goodiera repens (L.) R.Br.

Melampyrum sylvaticum $\mathrm{L}$.

Class Quercetea pubescentis Doing-Kraft ex Scamoni et Passarge 1959

Acer hyrcanum Fish. C. A. Mey. subsp.

hyrcanicum

Primula veris $\mathrm{L}$.

Clinopodium vulgare $\mathrm{L}$.

Potentilla micrantha Ramond ex DC

Tanacetum corymbosum (L.) Sch. Bip.

Physospermum cornubiense (L.) DC

Sorbus torminalis (L.) Crantz.

Evonymus verrucosus Scop.

Festuca heterophylla Lam.

Cornus mas L.

Digitalis lanata Ehrh.

Sorbus aria (L.) Crantz.

Digitalis viridiflora Lindt.

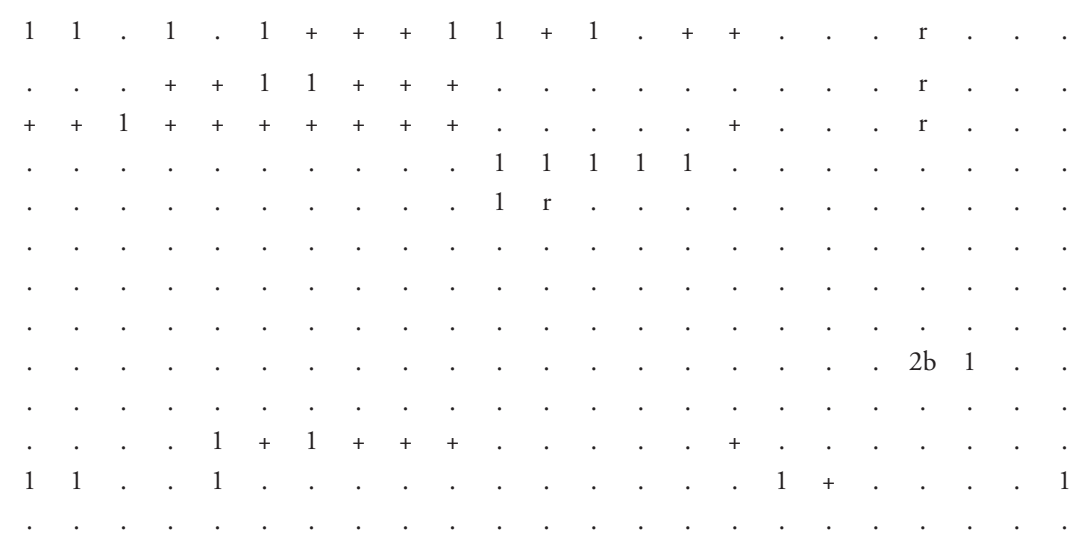



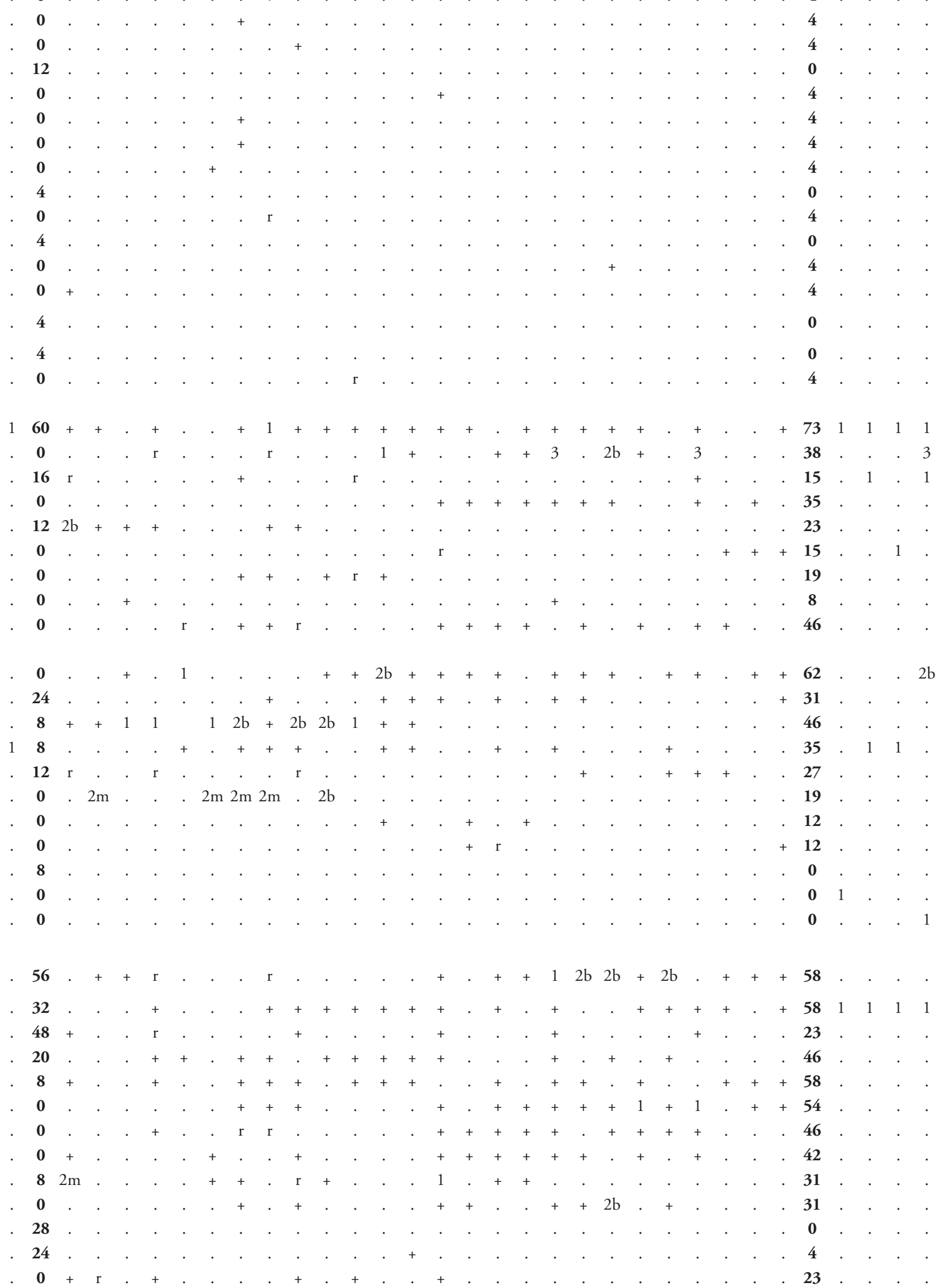
Campanula sparsa Friv.

Crataegus monogyna Jacq.

Carpinus orientalis Mill.

Juniperus oxycedrus L. subsp. deltoides

(R.P.Adams) N.G.Passal.

Syringa vulgaris $\mathrm{L}$.

Trifolium medium L. subsp. balcanicum Velen.

Cotinus cogyggria Scop.

Galium pseudaristatum Schur.

Vincetoxicum hyrundinaria Medicus

Acer hyrcanum Fish. C. A. Mey. subsp.

intermedium (Pančić) Palam.

Chamaecytisus frivaldskyanus (Degen) Kuzmanov

Coronilla emerus L. subsp. emeroides (Boiss. \&

Spruner) Holmboe

Quercus pubescens Willd.

\section{Other species}

Calamagrostis arundinacea (L.) Roth.

Fragaria vesca $\mathrm{L}$.

Cruciata glabra (L.) Ehrend.

Sorbus aucuparia L.

Teucrium chamaedrys $\mathrm{L}$.

Corylus avellana $\mathrm{L}$.

Geranium sanguineum $\mathrm{L}$.

Ajuga reptans $\mathrm{L}$.

Thesium bavarum Schrank

Dianthus petraeus Waldst. et Kit. subsp. petraeus

Origanum vulgare L.

Chamaecytisus austriacus (L.) Link.

Rubus saxatilis $\mathrm{L}$.

Campanula glomerata L. subsp. glomerata

Jurinea mollis (L.) Rchb. subsp. anatolica (Boiss.) Stoj.

Laser trilobum (L.) Borkh.

Seseli rigidum Waldst. et Kit. var. rigidum

Solidago virgaurea $\mathrm{L}$.

Coronilla varia $\mathrm{L}$.

Dorycnium herbaceum Vill.

Galium verum $\mathrm{L}$.

Polygonatum odoratum (Mill.) Druce

Polypodium vulgare $\mathrm{L}$.

Campanula rotundifolia $\mathrm{L}$.

Bryophyta sp. indent.

Rubus idaeus L.

Tussilago farfara L.

Asplenium trichomanes $\mathrm{L}$.

Astragalus monspessulanum $\mathrm{L}$.

Chamaecytisus ciliatus (Wahlenb.) Rothm.

Gentiana asclepiadea L.

Geranium macrorrhizum L.

Sedum ochroleucum Chaix

Vicia sepium L. 

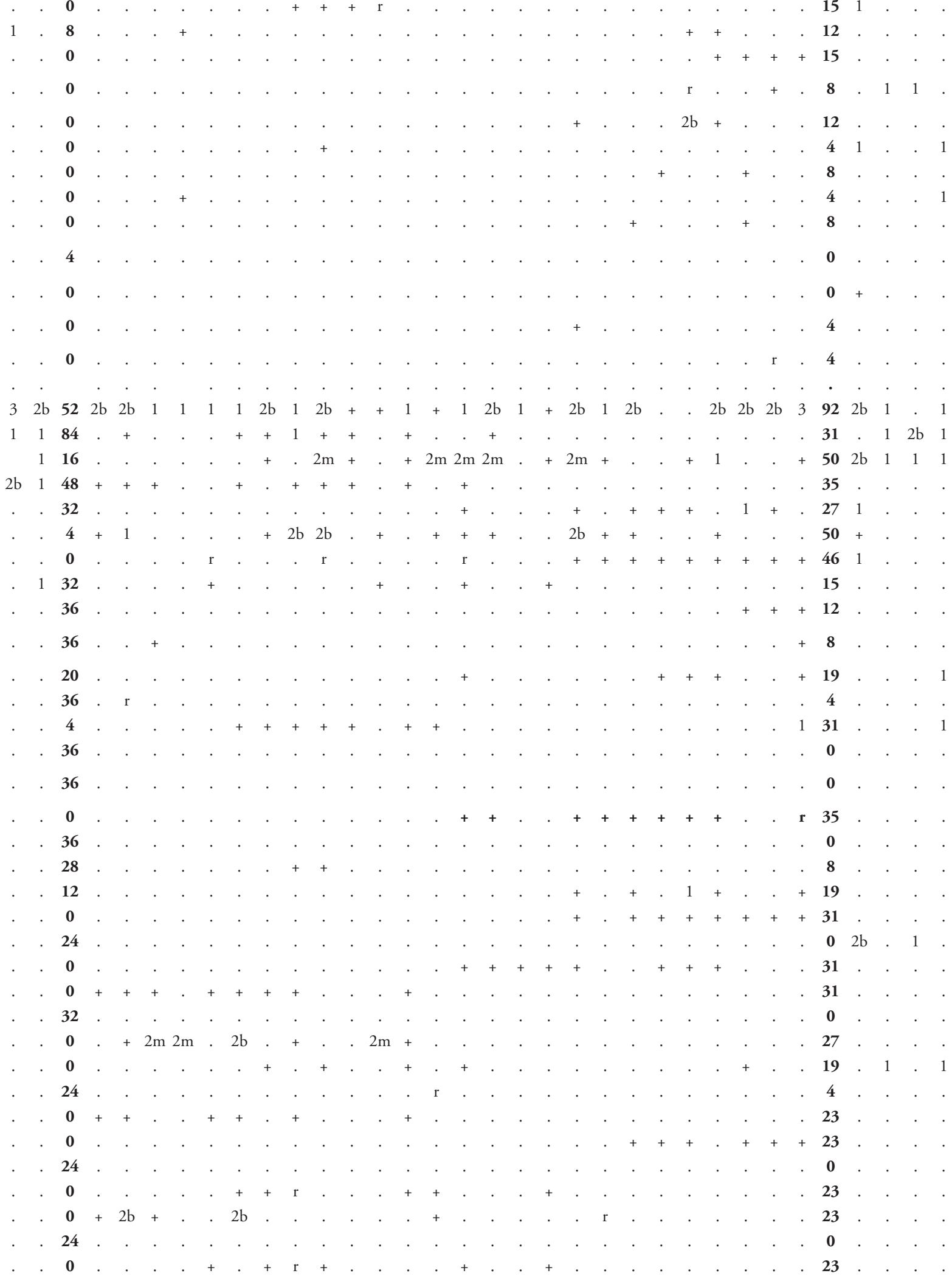
Viola odorata L.

Campanula cervicaria $\mathrm{L}$.

Campanula moesiaca Velen.

Carlina vulgaris $\mathrm{L}$.

Clematis vitalba $\mathrm{L}$.

Euphorbia cyparissias L.

Galium sp.

Lapsana communis $\mathrm{L}$.

Silene alba (Mill.) E. Krause

Festuca dalmatica (Hack.) K. Rich.

Rhamnus catharticus $\mathrm{L}$.

Saxifraga rotundifolia $\mathrm{L}$.

Scabiosa trinifolia Friv.

Thymus callieri Borbas ex Velen.

Asperula cynanchica L. subsp. cynanchica

Aster amellus $\mathrm{L}$.

Carex divulsa Stokes

Hypericum perforatum $\mathrm{L}$.

Juniperus sibirica Burgsd.

Peucedanum austriacum (Jacq.) Koch.

Scorzonera hispanica $\mathrm{L}$.

Senecio doria L. subsp. umbrosus (Waldst. \&

Kit.) Soó

Tanacetum vulgare $\mathrm{L}$.

Teucrium montanum $\mathrm{L}$.

Veronica chamaedrys $\mathrm{L}$.

Achillea ageratifolia (Sm.) Boiss.

Asplenium adianthum-nigrum $\mathrm{L}$.

Asplenium viride Huds.

Carlina acanthifolia All.

Carum graecum Boiss.\& Heldr.

Chondrilla urumoffii Degen

Dicranum scoparium Hedw.

Evonymus europaeus L.

Geum urbanum L.

Helianthemum nummularium (L.) Mill.

Heracleum ternatum Velen.

Hieracium villosum $\mathrm{L}$.

Hypericum maculatum Crantz.

Inula britannica $\mathrm{L}$.

Laserpitium latifolium L. var. latifolia

Linum hirsutum $\mathrm{L}$.

Orobanche sp.

Ranunculus montanus Willd.

Rosa obtusifolia Desv. (R. dumetorum)

Sedum hispanicum L.

Sesleria coerulans Friv.

Stachys recta L.

Thalictrum minus $\mathrm{L}$.

Trachelium rumelianum Hampe

Trifolium alpestre $\mathrm{L}$.

Achillea clypeolata Sm.

Achillea grandifolia Friv. 


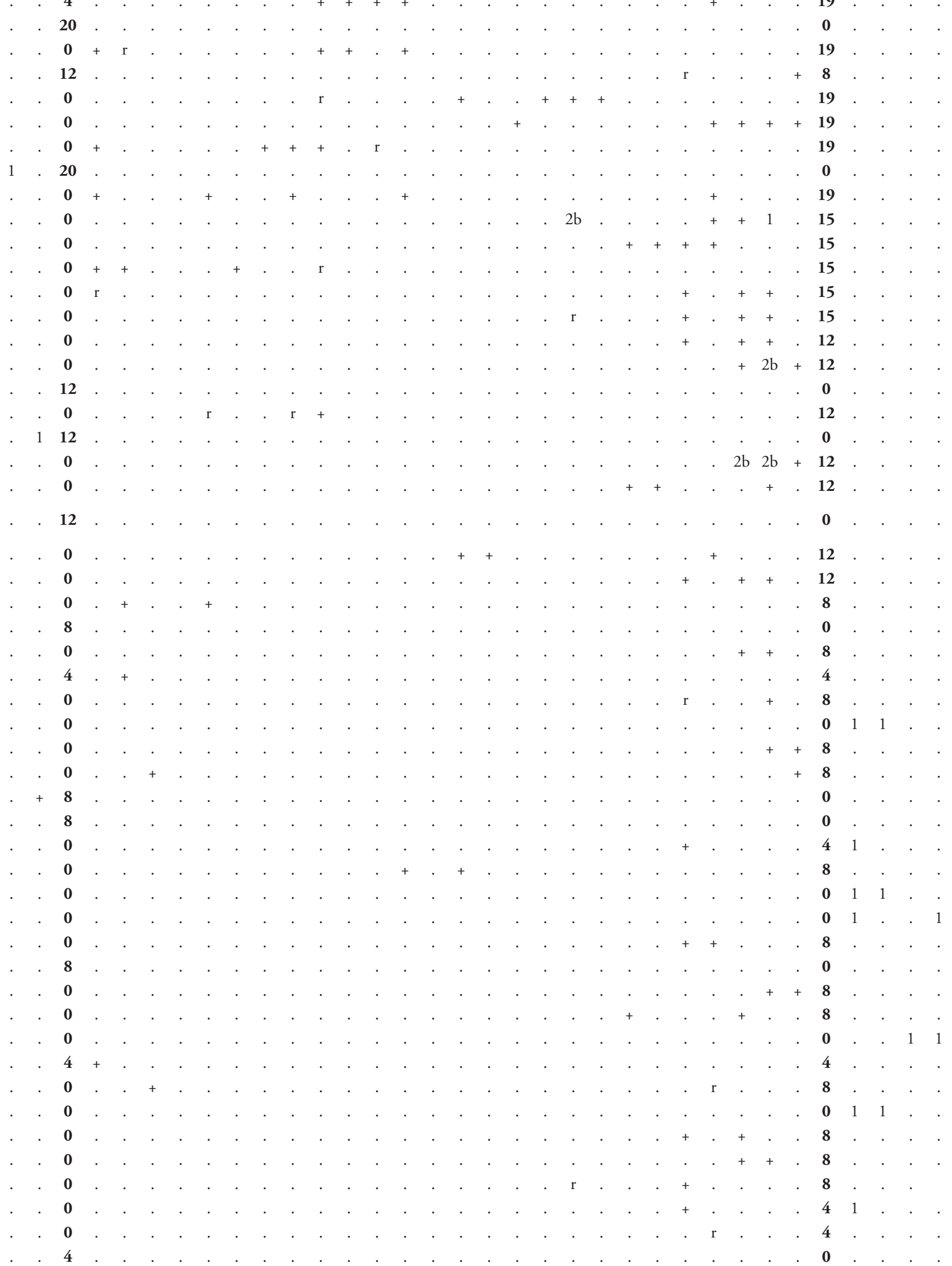


Acinos sp.

Aegopodium podagraria L.

Allium flavum $\mathrm{L}$.

Anthemis tinctoria L.

Anthericum liliago L.

Astragalus sp.

Briza maxima $\mathrm{L}$.

Briza media L.

Bromus tectorum L.

Centaurea stoebe L. gr.

Cystopteris fragilis (L.) Bernh.

Dianthus armeria $\mathrm{L}$.

Epilobium angustifolium $\mathrm{L}$.

Erophylla verna (L.) Chevall.

Euphorbia myrsinites L.

Euphrasia rostkoviana Hayne

Festuca nigrescens Lam.

Festuca valesiaca Schleich. ex Gaudin

Filipendula vulgaris Moench.

Fragaria viridis Duchense

Galium album Mill.

Galium aparine L.

Genista tinctoria L.

Gentiana cruciata L.

Geranium sylvaticum L.

Hieracium hoppeanum Schult.

Hieracium lachenalli Suter

Inula aschersoniana Janka

Lathyrus sylvestris $\mathrm{L}$.

Linum uninerve (Rochel) Borbas

Lobaria pulmonaria L.

Lotus corniculatus $\mathrm{L}$.

Lysimachia punctata L.

Melica ciliata L.

Micromeria frivaldszkyana (Degen) Velen. Micromeria cristata (Hampe) Griseb.

Minuartia rhodopaea (Degen) Kozuharov et

Kuzmanov

Moehringia pendula (Waldst. et Kit.) Fenzl.

Morus alba L.

Pastinaca sativa $\mathrm{L}$.

Pimpinella peregrina $\mathrm{L}$.

Pimpinella saxifraga $\mathrm{L}$.

Plantago lanceolata $\mathrm{L}$.

Platanthera bifolia (L.) Rich.

Pleurozium shreberi (Michx.) Trevis.

Poa pratensis $\mathrm{L}$.

Polygala major Jacq.

Potentilla erecta (L.) Raeusch.

Prunella vulgaris $\mathrm{L}$.

Ranunculus sprunerianum Boiss.

Rhytidiadelphus triquetrus (Brid.) Mitt.

Ribes alpinum L. 


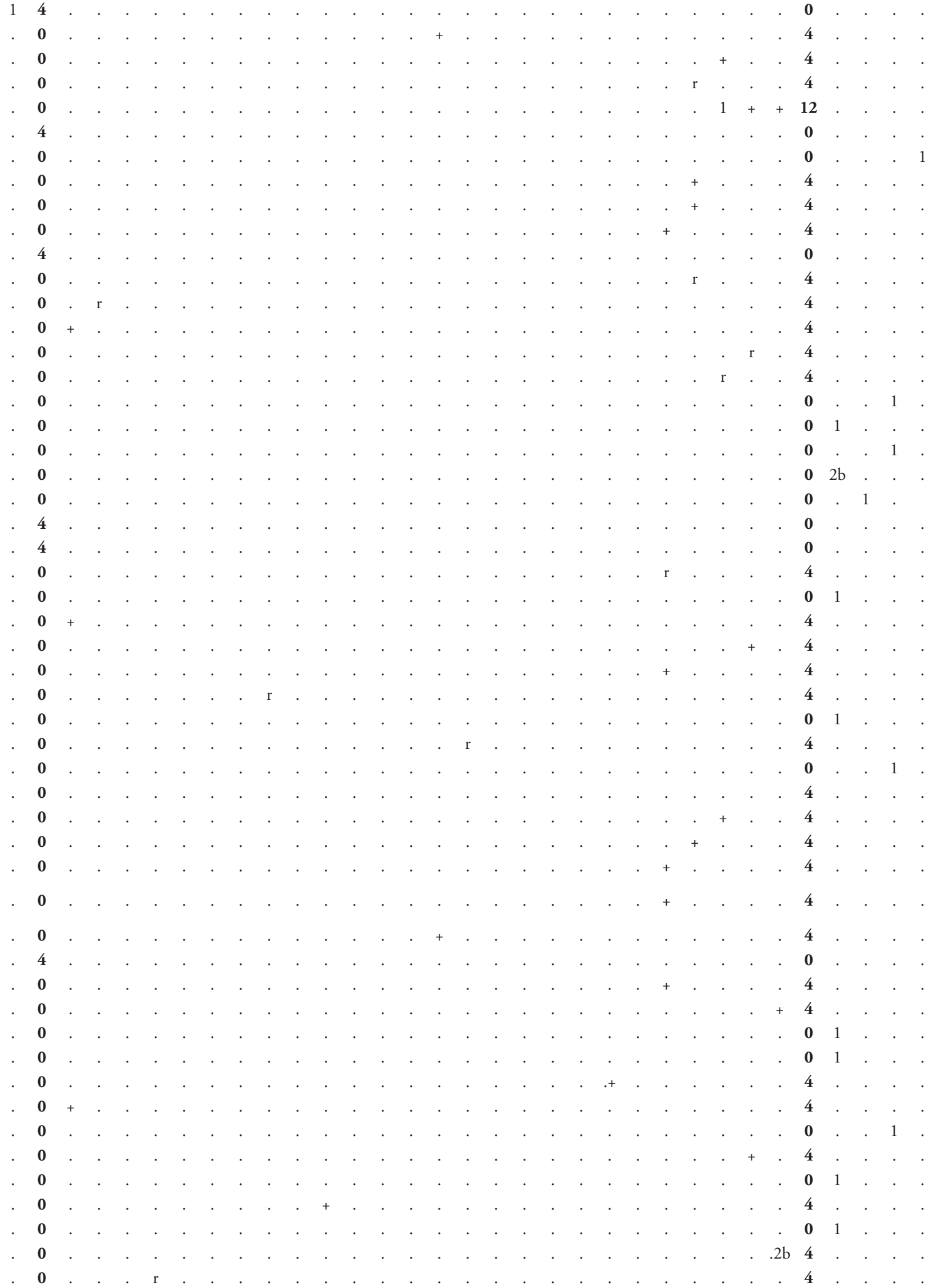


Rosa pimpineifolia $\mathrm{L}$.

Rubus caesius $\mathrm{L}$.

Rubus serpens Weihe ex Lej. et Court

Sagina procumbens $\mathrm{L}$.

Salix caprea L.

Sanguisorba minor Scop.

Saxifraga strybrnyi (Velen.) Podp.

Sedum maximum (L.) Suter

Selaginella helvetica (L.) Spring

Senecio sylvaticus L.

Seseli rhodopaeum Velen.

Silene vulgaris (Moench.) Garke

Stellaria graminea L.

Thalictrum simplex $\mathrm{L}$.

Thymus jankae Celak

Thymus striatus Vahl.

Trifolium montanum L.

Urtica dioica L.

Valleriana officinalis $\mathrm{L}$.

Veronica hederifolia L.

Viburnum opulus L.

Vicia cassubica L.

Vicia hirsuta (L.) Gray

Viola dacica Borbas 


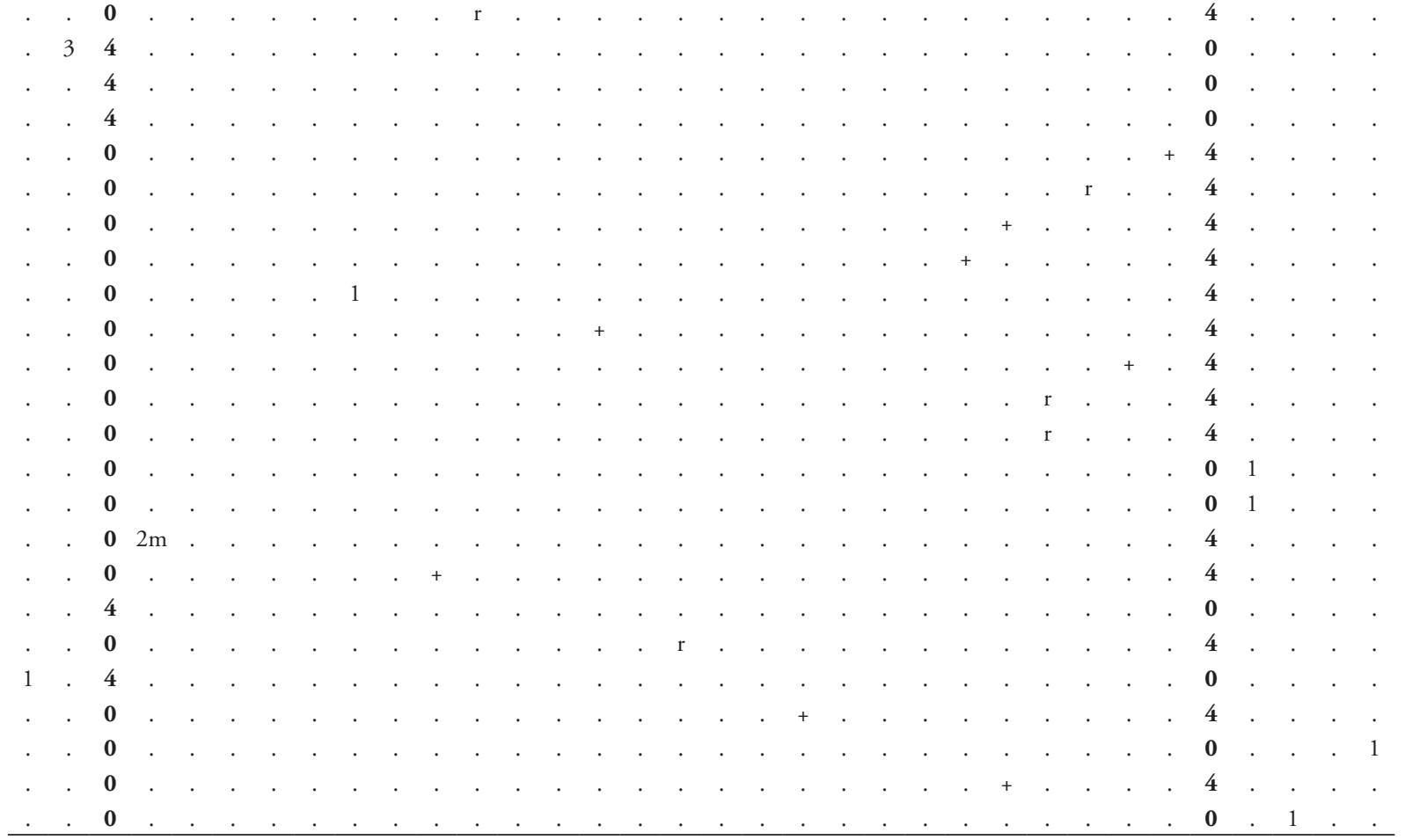

